\title{
Surface architecture of Histoplasma capsulatum
}

\author{
Allan J. Guimarães ${ }^{1,2}{ }^{*}$, Mariana D. de Cerqueira ${ }^{3}$ and Joshua D. Nosanchuk ${ }^{1,4}$ * \\ ${ }^{1}$ Department of Microbiology and Imunology, Albert Einstein College of Medicine of Yeshiva University, Bronx, NY, USA \\ ${ }_{2}^{2}$ Departamento de Imunologia, Instituto de Microbiologia Paulo de Góes, Universidade Federal do Rio de Janeiro, Rio de Janeiro, Brazil \\ ${ }^{3}$ Departamento de Microbiologia Geral, Instituto de Microbiologia Paulo de Góes, Universidade Federal do Rio de Janeiro, Rio de Janeiro, Brazil \\ ${ }^{4}$ Division of Infectious Diseases, Department of Medicine, Albert Einstein College of Medicine of Yeshiva University, Bronx, NY, USA
}

\section{Edited by:}

Michael H. Perlin, University of

Louisville, USA

Reviewed by:

Bjorn Sandrock, University of

Marburg, Germany

Jose M. Diaz-Minguez, University of

Salamanca CIALE, Spain

Erika Kothe, Friedrich Schiller

University, Germany

\section{*Correspondence:}

Allan J. Guimarães, Departamento de Imunologia, Centro de Ciências da

Saúde, Bloco I, Instituto de

Microbiologia Paulo de Góes,

Universidade Federal do Rio de

Janeiro, Avenida Carlos Chagas Filho

373, Rio de Janeiro 21941-902, Brazil.

e-mail: allan.guimaraes@phd.einstein.

yu.edu;

Joshua D. Nosanchuk, Albert Einstein

College of Medicine, 1300 Morris

Park Avenue, Bronx, NY 10461, USA

e-mail: josh.nosanchuk@einstein.

yu.edu
The dimorphic fungal pathogen Histoplasma capsulatum is the most frequent cause of clinically significant fungal pneumonia in humans. H. capsulatum virulence is achieved, in part, through diverse and dynamic alterations to the fungal cell surface. Surface components associated with $H$. capsulatum pathogenicity include carbohydrates, lipids, proteins, and melanins. Here, we describe the various structures comprising the cell surface of $H$. capsulatum that have been associated with virulence and discuss their involvement in the pathobiology of disease.

Keywords: Histoplasma capsulatum, surface, cell wall, architecture, proteins, carbohydrates

\section{INTRODUCTION}

Histoplasma capsulatum variety capsulatum $(\mathrm{Hc})$ is the causative agent of classical histoplasmosis (Meloan, 1952; Kwon-Chung, 1972, 1975; Bradsher, 1996) and the fungus has a worldwide distribution. The fungus is heterothallic and compatible $(+)$ and $(-)$ mating types unite to form the ascomycetous perfect stage designated Ajellomyces capsulatus.

$\mathrm{Hc}$ is a dimorphic fungal pathogen with two distinct morphological forms, filamentous and yeast, depending on a variety of nutritional factors and temperature (Maresca and Kobayashi, 1989). Hc is found in nature primarily as a saprophytic mold, and exists in soils enriched with organic nitrogen sources, like animal excrements (Emmons, 1950, 1956a,b; Zeidberg et al., 1952; Alteras, 1966; Emmons et al., 1966; Disalvo et al., 1970; Smith, 1971a,b). Additionally, the fungus can grow as a mold when cultured on laboratory mediums at less than $35^{\circ} \mathrm{C}$. The mold form is composed by hyaline septate hyphae that are $1-2.5 \mu \mathrm{m}$ diameter. Moreover, hyphae produce two different hyaline asexual reproduction structures. Macroconidia are large, thick-walled, round, and $7-15 \mu \mathrm{m}$ in diameter, typically tuberculate, knobby, or with short cylindrical projections, although they occasionally may be smooth. Microconidia are smooth-walled spherical, pyriform, or cigar shaped, ranging in size from 2 to $6 \mu \mathrm{m}$ in diameter (Edwards et al., 1960; Pine, 1960; Berliner, 1973; Garrison and Boyd, 1977). In contrast, the pathogenic single, budding yeast-like form is predominately isolated from infected tissue specimens and occurs when the microbe is grown at $\geq 37^{\circ} \mathrm{C}$ on specific media (Smith, 1971a,b; Hay, 1992). Hc var. capsulatum are generally small yeast cells $(2-4 \mu \mathrm{m}$ in length), thick-walled and ovoid with a narrow base at the smaller end, whereas variants found predominantly in Africa (Hc variety duboisii) produced larger yeast cells ( $8-15 \mu \mathrm{m}$ in length).

Infection typically occurs after disturbances in the environment which results in aerosolization of fungal propagules with subsequent inhalation of microconidia or hyphal fragments by a susceptible host (Guimaraes et al., 2006). Histoplasmosis is not generally associated with person to person spread of disease. However, vertical transmission was once observed in a human neonate (Kwon-Chung and Bennett, 1992). Rarely, histoplasmosis can be acquired by cutaneous inoculation of the fungus.

Histoplasmosis is a cosmopolitan fungal infection with areas of high endemicity. However, patients are usually unaware of their potential exposure (Wheat, 2003). Generally, the environmental conditions present in areas of high endemicity are a moderate climate with a relatively constant humidity (Maresca and Kobayashi, 1989). Endemic regions in North America are located in the Midwestern and Southeastern parts of the United States (USA), especially the Mississippi, Ohio, and Missouri river valleys, where $80 \%$ of the resident population has been shown to react to histoplasmin by skin testing (Ajello, 1971; Goodwin and Des Prez, 1978; Wheat, 1997). It is estimated that $\mathrm{Hc}$ is responsible for approximately half a million new human infections in the USA each year, making it the most prevalent pulmonary fungal pathogen (Cano and Hajjeh, 
2001). In Latin America, the most prevalent areas of endemicity are present within Brazil, Venezuela, Ecuador, Paraguay, Uruguay, and Argentina (Borelli, 1970; Wheat, 1997, 2001). In Brazil, endemic areas are located in the Midwestern and Southeastern portions of the country (Zancope-Oliveira et al., 2005; Guimaraes et al., 2006), where the prevalence ranges from 4.4 to $63.1 \%$ and 3.0 to $93.2 \%$, respectively (Londero and Ramos, 1978; Zancope-Oliveira et al., 2005; Guimaraes et al., 2006).

Exposure to $\mathrm{Hc}$ is exceedingly common for persons living within areas of high endemicity (Wheat and Kauffman, 2003). The clinical manifestations of disease range from asymptomatic infection or a mild influenza-like illness to a disseminated sepsis form that may involve virtually any tissue (Meloan, 1952; Csillag and Wermer, 1956; Goodwin and Des Prez, 1978; Wheat, 1994; Bradsher, 1996). These manifestations depend mainly on the magnitude of exposure (i.e., the number of fungal particles inhaled), the immunological status of the host, and the virulence of the infective strain, indicating that environmental and genetic factors regulate the manifestation of disease (Goodwin et al., 1981; Kauffman, 2007). The vast majority of infected persons have either no symptoms or a very mild illness that is never recognized as being histoplasmosis (Wheat et al., 2007). In fact, 95-99\% of the primary infections are not recognized in immunologically normal hosts in endemic areas (Saliba and Beatty, 1960; Isbister et al., 1976; Goodwin et al., 1981). Although the majority of symptomatic infections follow primary exposures to $\mathrm{Hc}$, reactivation of latent infection can result in significant disease, particularly in the setting of immunosuppression, such as individuals chronically receiving steroids or patients on chemotherapy (Kauffman, 2007). Furthermore, reactivation disease can be developed in liver transplant recipients with disease originating from latent infections in the transplanted organs (Limaye et al., 2000). Additionally, reactivation has increasingly occurred in patients receiving anti-cytokine therapies, especially inhibitors of gamma interferon (INF- $\gamma$ ) and tumor necrosis factor alpha (TNF- $\alpha$; Deepe, 2005; Deepe et al., 2005; Scheckelhoff and Deepe, 2005). Individuals with advanced HIV disease are also at significant risk for severe infection due to primary disease or reactivation of latent lesions, and disseminated disease occurs in 95\% of individuals with AIDS (Wheat, 1996). Additionally, in the setting of severe immunocompromised, Hc strains previously considered avirulent have been able to cause fatal disease (Davies et al., 1978; Wheat et al., 1990).

$\mathrm{Hc}$ is a model dimorphic pathogen for the study of invasive mycotic diseases. After inhalation, the fungal propagules reach the terminal bronchioles of the lung and deposits in alveoli, undergoing conversion to the pathogenic yeast form (Couto et al., 1994; Allendoerfer et al., 1997). As a facultative intracellular parasite, the interaction of $\mathrm{Hc}$ with macrophage cells is a critical component of the host response to infection (Newman, 2005) and is a complex and obscure phenomenon. Hc yeasts also have critical interactions with inflammatory neutrophils, and with dendritic cells (DCs) in the lung and other organs. Indeed, recent evidence suggests that DCs can restrict the differentiation of conidia into yeast (Newman, 2005; Newman et al., 2011) and may be the key antigen-presenting cells that initiate cell-mediated immunity (Deepe et al., 2008). Hc yeast cells must survive and/or subvert the hostile anti-microbial environmental within phagocytes (Allendoerfer et al., 1997), including fungicidal mechanisms dependent on hydrogen peroxide and products of the nitric oxide synthase (NOS) pathway (Eissenberg and Goldman, 1987). Yeast cells actively inhibit phagolysosomal fusion, thereby preventing exposure to the acidic hydrolytic enzymes of the lysosomes. Hc also prohibits accumulation of vacuolar ATPase, which is important for proton accumulation in phagosomes, and the fungus can actively alkalinize phagosomal pH to 6.5 (Strasser et al., 1999). Within the phagocytes, yeast may travel to hilar and mediastinal lymph nodes where they can gain access to the blood circulation for dissemination to various organs, such as liver and spleen (Wheat and Kauffman, 2003).

\section{YEAST CELL SURFACE}

The components of the yeast surface are the main interface of $\mathrm{Hc}$ to communicate with its environment and to interact with cells of the immune system. In particular, Hc yeast display several surface molecules involved in entry and survival within the host (Figures 1 and 2). The cell wall is essential to diverse aspects of Hc biology and pathogenicity (Table 1). As discussed, uptake of Hc yeast by macrophages provides a protected environment for yeast growth and replication. However, in promoting its phagocytosis, Hc must also subvert or avoid activating macrophage antifungal defenses.

\section{CELL WALL CARBOHYDRATES}

The cell wall is composed of about $80 \%$ of saccharides in dry weight (Bernard and Latg, 2001). The monosaccharide composition consists in glucose (Glc), which is the most abundant monosaccharide in filamentous and yeast cell wall, followed by mannose (Man), and galactose (Gal). Structurally, the sugars form a rigid polysaccharide structure that varies in composition ratios depending on the chemotype of the strain (Reiss, 1977; Reiss et al., 1977). Although different glycans comprise the structure; some fluctuations can occur in certain isolates from a single chemotype, such as shown with a major fibrillar chitin skeleton component, $\alpha$ 1,3-glucan, $\beta$-1,3-glucan, and soluble galactomannan (Kanetsuna et al., 1974).

The yeast and mycelia phases of Hc contain different chitin fibril arrangements within their cell walls (Kanetsuna, 1981). These structures are the foundation of the dynamic immunoreactive construction that comprises the Hc cell wall.

The $\alpha$ and $\beta$-glucans present in the cell wall also change during morphogenesis and have different biological roles (Domer et al., 1967; Domer, 1971). At room temperature, the production of $\beta$ glucan is favored, resulting in increased amounts of this glucans which is predominant in the fungal mycelial phase. Also, induction of 3-glucanase activity promotes a decrease of cell wall rigidity, resulting in elongation or budding $(2,3)$. The $\beta$-1,3-glucan consists of a linear $\beta$-1,3-glucosyl-linked backbone with $\beta-1,6$ glucosyl-linked side chains that vary in length and distribution, while forming a complex tertiary structure stabilized by interchain hydrogen bonding (Kanetsuna et al., 1974). This structure is antigenic and participates in the modulation of the host immune response (Gorocica et al., 2009).

A shift to $37^{\circ} \mathrm{C}$ favors $\alpha$-1,3-glucan synthesis and low $\beta$ 1,3 -glucan synthetic activity during yeast growth. During phase transition from mycelia to yeast, the synthesis of $\alpha$-glucans increases rapidly (Kanetsuna et al., 1972; Kanetsuna, 1981) and this effect is strictly dependent on temperature, with a lower synthesis at 20 than $37^{\circ} \mathrm{C}$. Hc $\alpha$-glucan contains $\alpha$-1,3-glucosyl linear 


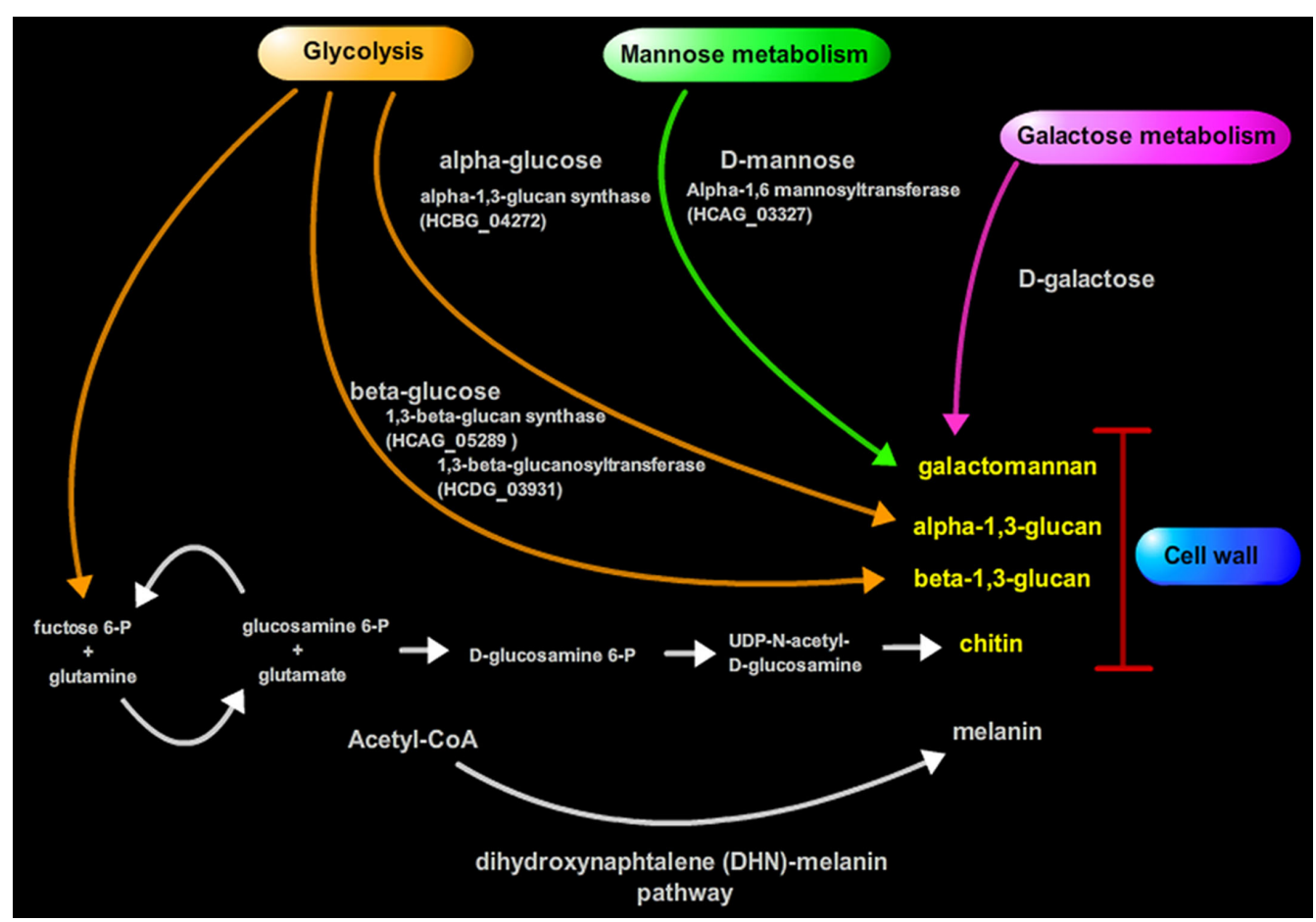

FIGURE 1 | Biosynthesis of important cell wall components of Hc.

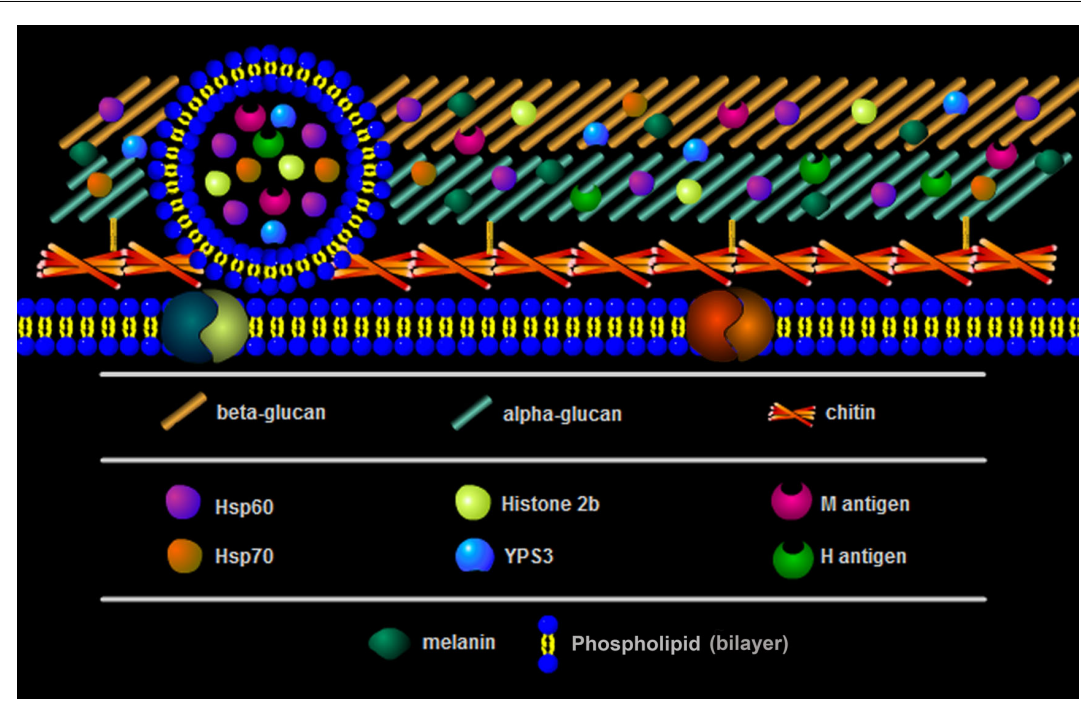

FIGURE 2 | Schematic model showing the composition of the Hc cell wall.

residues and topographically overlaps the $\beta$-glucan surrounding this last polymer in the yeast cell wall and it is considered relevant for Hc yeast virulence (Klimpel and Goldman, 1988; Rappleye et al., 2004).

Based on the $\alpha$-1,3-glucan content of the yeast cell wall, $\mathrm{Hc}$ is classified as chemotype I or II (Domer et al., 1967; Domer, 1971). A strain is classified as chemotype I when the $\alpha-1,3$-glucan is absent and it the fibers are entirely $\beta$-linked (Davis et al.,
1977). A chemotype II cell wall contains a mixture of $\alpha$ and $\beta-1$, 3-glucans.

\section{Chitin}

The major cell wall component is an inner layer of chitin, a polysaccharide composed by polymers of glucans and $\beta-1,4-N$ acetyl-glucosamine (GlcNAc) residues (Kanetsuna et al., 1974). The chitin fibrils are considered to be the skeleton of the cell 
Table 1 | Components of Hc cell surface and their role in pathogenicity/virulence.

\section{Surface component Role in virulence/pathogenicity}

\section{SURFACE CARBOHYDRATES}

Chitin

$\beta-1,3$-glucan

$\alpha-1,3-$ glucan

Gallactomannan

Lectin-like components

Mannoproteins

\section{LIPIDS}

Ceramide monohexoside

Extracellular vesicles
Maintenance of cell wall integrity and rigidity, as well as in resisting the extracellular environment (Ruiz-Herrera and Osorio, 1974); immunomodulatory; and immunosuppressing molecule recognized by dectin-1 (Mora-Montes et al., 2011) inducing activation of anti-microbial activities of macrophages and PBMCs, (Rementeria et al., 1997; Mora-Montes et al., 2011); bind diverse products in supernatant, such as polysaccharides such as Cryptococcus neoformans capsule or self-proteins like YPS3 (Bohse and Woods, 2005).

Major constituent of the cell wall of the filamentous phase of Hc (Davis et al., 1977); promotes inflammatory cell recruitment and production of pro-inflammatory cytokines including TNF- $\alpha$ (Figueiredo et al., 1993; Medeiros et al., 1999, 2004; Anjos et al., 2002). Dectin-1 and DC-SIGN (CD209) are receptors for $\beta$-1,3-glucan polymers (Brown, 2006).

Presence correlated with virulence (Kugler et al., 2000; Rappleye et al., 2007); regulates yeast proliferation inside host phagocytes (Kugler et al., 2000) by protecting the yeast within phagolysosomes (Eissenberg and Goldman, 1991), resulting in a state called intracellular latency (Eissenberg et al., 1996, 1997); Hc displaying $\alpha-1,3-g l u c a n s$ can persist for several weeks inside these cells and induce the formation of granulomas, which result in chronic infected tissues (Klimpel and Goldman, 1988); loss of $\alpha-1,3-$ glucan impaired Hc yeast proliferation within macrophages killing of cultured macrophages (Rappleye et al., 2004); in vivo, loss of $\alpha$-1,3-glucan resulted in reduction in lung colonization (Marion et al., 2006); subverts the host immune mechanisms of recognition of cell wall components and contributes to yeast survival. By blocking the innate recognition of the fungal PAMP $\beta$-1,3-glucan by its PRR dectin-1 receptor on host phagocytes (Rappleye et al., 2007). Involved in DTH with inhibition of macrophage migration factor release (Azuma et al., 1974; Reiss et al., 1974). In Paracoccidioides brasiliensis, it appears to be involved in the protection against its own serine-thiol protease, an enzyme associated with pathogen dissemination through the extracellular matrix (Matsuo et al., 2006).

Binds to a 68 KDa galactosylated surface molecule (mainly $\beta$-anomer) on murine macrophages (Taylor et al., 1998; DuarteEscalante et al., 2003), and participates in macrophage activation, and regulation of phagocytosis (Maldonado et al., 1998). Also involved in agglutination of human erythrocytes (Taylor et al., 2004).

Highly antigenic and can lead to dendritic cell maturation and activation with pro-inflammatory cytokine production, (Pietrella et al., 2006). Also involved in host tissue adherence (Ross, 2002).

Expressed in almost all fungal species (Barreto-Bergter et al., 2004); found in the mycelia and yeast phases of Hc (Bar and Lester, 1984; Barr et al., 1984) and appears to be required for fungal survival (Dickson and Lester, 1999).

Carry lipids, proteins, polysaccharides, and pigment-like structures involved in diverse processes including metabolism, cell recycling, signaling, and virulence Noneda and Doering, 2006; Rodrigues et al., 2007, 2008a; Albuquerque et al., 2008; Vallejo et al., 2011); some proteins found in Hc vesicles are pathogenic determinants and/or are involved in host-pathogen interactions. Hc extracellular vesicle may function as a "virulence bag," since virulence factors are concentrated within them and these molecules can modulate the host-pathogen interaction and immune response (Albuquerque et al., 2008 ; Rodrigues et al., 2008b; Casadevall et al., 2009; Oliveira et al., 2010).

\section{PROTEINS}

Hsp60

Major ligand that mediates attachment of Hc to macrophage/monocyte CR3 integrin (CD11b/CD18; Long et al., 2003), resulting in phagocytosis (Long et al., 2003; Habich et al., 2006); it is also an immunogenic molecule, being a potential target for passive immunization therapy (Guimaraes et al., 2009, 2011a); contributes with cell wall changes that allow the pathogen to survive under stress conditions (Shaner et al., 2008); interacts with a large diversity proteins in both cytoplasmic and cell wall fractions, participating as a key regulator of several cellular processes, including amino acid, protein, lipid, and carbohydrate metabolism, cell signaling, replication, and expression of virulence associated proteins (Guimaraes et al., 2011c).

Hsp70

Recombinant Hsp70 elicits a cutaneous delayed-type hypersensitive response in mice; however, vaccination with Hsp70 did not confer protection against Hc infection (Allendoerfer et al., 1996); Hsp70 is highly expressed by the fungus when undergoing transition from mycelium-to-yeast (Kamei et al., 1992) and has its peak of expression at $37^{\circ} \mathrm{C}$ (Shearer et al., 1987). Hsp70 synthesis increases soon after heat shock (Lambowitz et al., 1983; Shearer et al., 1987) and we demonstrated more interactions between $\mathrm{Hsp} 70$ and $\mathrm{Hsp60}$ at elevated temperatures.

M antigen Major diagnostic antigen of Hc as it elicits intense humoral and cellular immune responses (Hamilton et al., 1990; Deepe, 1994; Deepe and Durose, 1995; Hamilton, 1998; Zancopé-Oliveira et al., 1999; Guimaraes et al., 2006). Its cell surface localization makes the $\mathrm{M}$ antigen the most important catalase for detoxification of host derived peroxides, protecting the fungus against oxidative stress, and also makes this protein accessible to host immune cells and antibody (Guimaraes et al., 2008). 


\section{Table 1 | Continued}

\section{Surface component}

$\mathrm{H}$ antigen

$\mathrm{H} 2 \mathrm{~B}$

YPS3

Melanin

\section{Role in virulence/pathogenicity}

Involved in nutrient acquisition (Woodward and Wiseman, 1982) or modulation of cell wall architecture (Kruse and Cole, 1992; Deepe and Durose, 1995; Akiyama et al., 1998; Fisher et al., 1999; Fisher and Woods, 2000); vaccination with H antigen protected mice in a pulmonary histoplasmosis model (Deepe and Gibbons, 2001) associated with production of IFN- $\gamma$, GM-CSF, IL-4, and IL-10 by splenocytes and in parallel, there was major expansion of $\mathrm{CD}^{+}{ }^{+}$or $\mathrm{CD} 8^{+}$cells in spleens of mice (Deepe and Gibbons, 2001).

Important in cell-cell signaling and modulation of the immunoresponse by the fungus (Nosanchuk et al., 2003); mAbs againt this protein enhanced levels of IL-4, IL-6, and IFN-gamma in the lungs of infected mice. The mAbs increased phagocytosis of yeast by J774.16 cells through a CR3-dependent process and uptake of the opsonized yeast cells was associated with yeast cell growth inhibition and killing (Nosanchuk et al., 2003; Nosanchuk, 2005). The altered intracellular fate of the opsonized Hc yeast was characterized by significantly enchanced macrophage phagosome activation and maturation and also a reduced ability of the organism to regulate the phagosomal $\mathrm{pH}$. Opsonization also increased antigen processing and reduced negative PD-1/PDL-1 co-stimulation in macrophages, resulting in more-efficient T-cell activation (Shi et al., 2008). YPS3 is able to bind chitin and it is linked to $\mathrm{Hc}$ virulence in vivo and associated with increased fungal burden in phagocyte-rich tissues, such spleen and liver (Bohse and Woods, 2007b).

Hence, Hc cell wall melanin protects the fungus from a myriad of insults and the polymeric nature of the pigment enhances its structural strength. It protects against extremes in temperatures, radiation, and predation in the environment, free radicals, defensins, and other toxic responses within a host. Melanization of Hc protects the fungus against chemotherapy with amphotericin B or echinocandins (van Duin et al., 2002; Gomez and Nosanchuk, 2003). wall, playing a structural role in maintaining cell wall integrity and rigidity, as well as in resisting the extracellular environment (Ruiz-Herrera and Osorio, 1974). The chitin layer is attached to the non-reducing end of the outer $\beta$-1,3-glucan chain by a $\beta-1,4$ linkage (Mol and Wessels, 1987), and as for the number of chitin$\beta$-1,3-glucan linkages compared to the total number of linkages in the cell wall, the ratio is about one chitin-glucan bond per 8,000 hexose units. Experiments with appropriate mutants lacking such linkage, have shown that their cell wall are weaker and more prone to damage (Bulawa et al., 1995).

The immunoreactivity of Hc chitin with host cells has not been formally investigated. Nevertheless, several chitin-binding proteins had been described, such as RegIIIg (HIP/PAP), a C-type lectin expressed in the neutrophil-like Paneth cells of the small intestine (Cash et al., 2006), and FIBCD1, a calcium-dependent acetyl group-binding receptor that is also expressed in the gastrointestinal tract (Schlosser et al., 2009). The cells of the immune system seem to use dectin-1 to recognize Candida albicans (MoraMontes et al., 2011) through chitin, but in Hc, the role of chitin in the interaction with the components of the immune system is unclear. However, it is possible that chitin functions as an immunomodulatory molecule, immunosuppressing, or activating anti-microbial activities of macrophages and PBMCs, as described in C. albicans (Rementeria et al., 1997; Mora-Montes et al., 2011). Intriguingly, Hc chitin can bind diverse products in supernatant, such as polysaccharides from the capsule of Cryptococcus neoformans or self-proteins like YPS3 (Bohse and Woods, 2005), described later in this essay. Hence, chitin plays diverse roles in interacting with host cells and diverse compounds in the local environment.

\section{$\beta-1,3-g l u c a n$}

Surrounding chitin, there is a layer comprised of glucans polymers linked by a $\beta-1,3$ linkage. This polymer is a major constituent of the cell wall of the filamentous phase of $\mathrm{Hc}$ and in chemotype I Hc yeasts, where the glycan layer is entirely $\beta$-linked (Davis et al., 1977). Some biological functions have been attributed to the $\beta$-1,3-glucan, such as promotion of inflammatory cell recruitment to the site of infection and production of pro-inflammatory cytokines including TNF- $\alpha$ (Figueiredo et al., 1993; Medeiros et al., 1999, 2004; Anjos et al., 2002). Intriguingly, $\beta$-glucans possess many of the characteristics attributed to PAMPs and are known to be potent triggers of innate immunity (Brown, 2006). Dectin-1 and DC-SIGN (CD209) are receptors for $\beta$-1,3-glucan polymers (Brown, 2006). Dectin-1, a non-classical C-type lectin major nonopsonic $\beta$-glucan receptor, was one of the first PRRs identified that can mediate its own signaling or act synergistically with Toll-like receptors (TLR) to initiate specific responses to infectious agents. Dectin-1 has been shown to mediate inflammatory responses to fungi and facilitate pathogen clearance (Steele et al., 2005). Detection of glycosylated fungal components by this receptor occurs in DCs, neutrophils, natural killer, and subsets of $\mathrm{T}$ cells and can result in the induction of cellular responses, including ligand uptake by phagocytosis and endocytosis, DC maturation, respiratory burst, and synthesis of a number cytokines, including TNF, IL-10, IL-2, IL-23, and IL-6 as well as chemokines like CXCL2 (Brown, 2006; Dennehy and Brown, 2007). DC-SIGN, another C-type lectin involved in recognition of $\beta$-glucans, is expressed primarily by DCs (Koppel et al., 2005) and has been proposed to mediate engulfment of certain fungi (Cambi et al., 2003; Koppel et al., 2005; Serrano-Gomez et al., 2005).

Due to its immunogenicity and predominance in cell wall, $\beta$ glucans have been studied as a potential target for vaccination. In fact, a vaccine based on glucan-laminarin conjugate with the recombinant diphtheria toxoid CRM197 (Lam-CRM197) recently tested was able to induce a protective immunity against different pathogenic fungi, such as $C$. albicans and A. fumigates in vivo (Torosantucci et al., 2005; Bromuro et al., 2010). Limitation of 
$\beta$-glucan exposure is one mechanism shaping the overall pathogenic potential of different medically important fungi including Hc. However, several membrane components, such as CR3 can interact with $\beta$-glucan (Kataoka et al., 2002). Consequently, the abrogation of the host immune response by blocking Dectin-1 may be circumvented by other $\beta$-glucan receptors during natural host interactions. However, certain Hc pathogenic strains mask $\beta$-glucan by an outer $\alpha$-1,3-glucan layer.

\section{$\alpha-1,3-g l u c a n$}

Morphological transition from filamentous to yeast phase modifies the biosynthesis of the glucans pool, with the production of the $\alpha-1,3$-glucan, which is a specific attribute of the Hc yeast phase (Kanetsuna et al., 1974; Klimpel and Goldman, 1988). $\alpha$ 1,3-Glucan is also common to most medically important fungi, including all the other dimorphic pathogenic species. However, the cell walls of Hc chemotype I strains lack the $\alpha$-1,3-glucan polymer, but contain more chitin and less glucan than chemotype II (Domer et al., 1967; Domer, 1971). Some strains of Hc spontaneously produce variants lacking $\alpha$-1,3-glucan that display reduced virulence (Kugler et al., 2000; Rappleye et al., 2007). Such phenomena can also be induced by successive laboratory passages of the Hc yeast (Klimpel and Goldman, 1988; Hogan and Klein, 1994). In other dimorphic fungi, spontaneous loss of $\alpha$ 1,3-glucan also correlates with reduced virulence, indicating this may be a conserved mechanism of fungal pathogenicity (Klimpel and Goldman, 1988; Hogan and Klein, 1994). In general, several studies have demonstrated that virulent Hc strains contain up to 1,000 -fold more $\alpha$-1,3-glucan than avirulent strains.

Most recently, the importance of $\alpha$-1,3-glucan in chemotype II Hc virulence was examined in spontaneous mutants, and by RNA interference and traditional allelic replacement of the gene that encodes for $\alpha$-1,3-Glucansynthase (ags1; Rappleye et al., 2007). Loss of $\alpha$-1,3-glucan does not impair growth of Hc in vitro. However, the loss significantly impaired the proliferation of the yeast in macrophages in vitro and these yeast were less able to kill cultured macrophages (Rappleye et al., 2004). In an in vivo model, loss of $\alpha$-1,3-glucan resulted in a substantial reduction in lung colonization, suggesting that $\alpha-1,3$-glucan might be a virulence determinant designed specifically for survival and replication in murine respiratory infection models (Marion et al., 2006).

The regulation of $\alpha$-1,3-glucan occurs upstream AGS-1, by the function of the amy1 and ugpl gene products, respectively, an $\alpha-1,4$-amylase involved in the synthesis of $\alpha$-1,3-glucan (Marion et al., 2006) and an UTP-glucose-1-phosphate uridylyltransferase that synthesizes UDP-glucose monomers. As observed with AGS1, loss of AMY1 and UGP1 function reduces the virulence of Hc, with attenuation of yeast to grow within or kill macrophages, and a reduced capacity to colonize murine lungs (Marion et al., 2006).

However, the exact mechanism for how $\alpha$-1,3-glucans alters Hc pathogenesis remains poorly understood and, to date, there is no identified receptor to $\mathrm{Hc}$ cell wall $\alpha$-1,3-glucans. In a Pseudallescheria boydii model, this carbohydrate seems to be important in phagocytic internalization, which stimulates the secretion of inflammatory cytokines trough the involvement of TLR2, CD14, and MyD88 (Bittencourt et al., 2006). As described above, the explanation for their modifying effect on virulence may primarily be due to their influence in the host-pathogen interactions achieved by subverting the host immune mechanisms of recognition of cell wall components and contributing to yeast survival. As the $\alpha-1,3$-glucans are expressed as the most external cell wall layer, they block innate recognition of the fungal $\beta$-1,3-glucan by dectin-1 receptor on host phagocytes (Rappleye et al., 2007). Blockage of this receptor suppresses the production of pro-inflammatory cytokine TNF- $\alpha$, consisting in an important virulence mechanism for $\mathrm{Hc}$, but it also helps explain mechanistically the higher native pathogenicity of dimorphic fungi. Yeasts which also lack $\alpha$-1,3-glucan have reduced capacity to cause significant disease. Consistent with this hypothesis, the parasitic forms of the dimorphic fungal pathogens each possess $\alpha$-1,3-glucan and can cause disease even in the face of normal host immune function. However, this does not explain how chemotype I strains maintain virulence in the absence of $\alpha$-1,3-glucans. Additional functions have been attributed to $\alpha$-1,3-glucans, such regulation of yeast proliferation inside host phagocytes (Kugler et al., 2000) by protecting the yeast within phagolysosomes (Eissenberg and Goldman, 1991), thus resulting in a state called intracellular latency (Eissenberg et al., 1996, 1997). Hc displaying $\alpha$-1,3-glucans can persist for several weeks inside these cells and induce the formation of granulomas, which result in chronically infected tissues (Klimpel and Goldman, 1988).

\section{Galactomannans}

Hc galactomannan-protein complexes have antigenic activities, and can induce delayed-type hypersensitivity (DHT) in guinea pigs with inhibition of macrophage migration factor release (Azuma et al., 1974; Reiss et al., 1974). It is noteworthy that fungal galactomannan complexes in the related dimorphic fungus Paracoccidioides brasiliensis appear to be involved in the protection of the organism against its own serine-thiol protease, an enzyme associated with pathogen dissemination through the extracellular matrix (Matsuo et al., 2006).

\section{Lectin-like components}

Interactions between carbohydrates and lectins are considered the basis of recognition of target particles by phagocytes (Sharon, 1984). The expression of lectins by pathogenic microorganisms has been correlated to the organism attachment and invasion to host tissues (Mendes-Giannini et al., 2000; Singh et al., 2011). Interestingly, $\mathrm{Hc}$ has components with lectin activity on the yeast surface that can bind to surface molecules on murine macrophages (Taylor et al., 1998; Duarte-Escalante et al., 2003). It has been shown that a lectin-like molecule plays a role in the binding to macrophage surface proteins suggesting that the specific receptor for histoplasmin components on macrophage could be an oligosaccharide-protein complex containing galactose (mainly $\beta$-anomer) as determinant, since enzymatic cleavage of galactosyl residues or a galactose $N$-acetyl-D-galactosamine compound reduced this interaction (Maldonado et al., 1994, 1998; Taylor et al., 1998). The macrophage surface ligand is a $68 \mathrm{kDa}$ protein and seems to participate in macrophage activation and regulation of phagocytosis (Maldonado et al., 1998; Taylor et al., 1998). Hc also has the ability to bind and agglutinate human erythrocytes using this lectin-like component (Taylor et al., 2004). 
$\mathrm{Hc}$ also expresses a $50 \mathrm{kDa}$ lectin that recognizes sialic acid residues on laminin, a key component of the membrane basement protein (Mcmahon et al., 1995) and might function as a possible mechanism for dissemination or is involved in cell-cell interactions.

\section{Other cell wall associated carbohydrates}

Several additional carbohydrates contribute to the composition of the Hc cell wall. Mannans and mannosylated proteins are found in the cell wall of Hc and several fungi, and their importance has been best described in C. albicans (Lipke and Ovalle, 1998; Pietrella et al., 2008). These mannoproteins are highly antigenic and can lead to DCs maturation and activation followed by pro-inflammatory cytokine production, which drives a protective T-cell response (Pietrella et al., 2006). In addition, mannans have been implicated in host tissue adherence (Ross, 2002).

\section{CELL WALL LIPIDS}

Lipids have recently emerged as important bioactive molecules in fungi in addition to being critical structural components of cellular membranes. Several structurally and functionally distinct lipids have been characterized in fungi. Based on simple extractions with organic solvents and determination of the total lipid content in Hc cell wall fractions, earlier reports have shown that it corresponded to $3-10 \%$ of the cell wall dry weight (Macwilliam, 1970; Cox and Best, 1972). For example, ceramide monohexoside (CMHs) consists of a lipid (ceramide) moiety linked to a single sugar residue. This molecule is the simplest glycosphingolipid of eukaryotic cells and it is expressed in almost all fungal species (Barreto-Bergter et al., 2004). In C. neoformans, glucosylceramide has been shown to be cell wall associated and concentrates at specific sites during cell division (Rodrigues et al., 2000). Additionally, antibodies to glucosylceramide have been shown to inhibit $C$. neoformans and $F$. pedrosoi growth and budding (Rodrigues et al., 2000; Nimrichter et al., 2004), block mycelium formation in the plant pathogen Colletotrichum gloeosporioides (Da Silva et al., 2004), interfere with filamentation in $P$. boydii, and inhibit germ-tube formation in C. albicans (Pinto et al., 2002). CMHs components have been identified in neutral lipids extracted from both filamentous and yeast Hc (Toledo et al., 2001a). Indirect immunofluorescence using an IgG2a monoclonal antibody (mAb) to glucosylceramide, termed MEST-2, labeled the surface of Hc yeast suggesting a cell wall/membrane localization of this molecule (Toledo et al., 2001b). In Hc, the significance of this molecule has not been elucidated. However, the glycosylinositol phosphorylceramides found in the mycelia and yeast phases of Hc (Barr and Lester, 1984; Barr et al., 1984) appears to be required for fungal survival (Dickson and Lester, 1999).

\section{EXTRACELLULAR VESICLES}

Macromolecules need to be transferred from the intracellular to the extracellular space through the rigid, complex, and dense cell wall environment.

Recently, Hc extracellular vesicles composed by a lipid bilayer have been described and appear to be secreted through and are present at least transiently in the cell wall (Albuquerque et al., 2008). Using transmission electron microscopy, biochemistry, proteomics, and lipidomics analysis, we and other investigators have described the vesicular transport in fungal pathogens (Yoneda and Doering, 2006; Rodrigues et al., 2007, 2008a; Albuquerque et al., 2008; Vallejo et al., 2011), including C. neoformans, C. albicans, C. parapsilosis, Sporothrix schenckii, Saccharomyces cerevisiae, $P$. brasiliensis, and Hc. The cellular origin of the extracellular vesicles remains unknown but there is evidence for the participation of different pathways of cellular traffic in vesicle biogenesis (Oliveira et al., 2010). Remarkably, morphological and biochemical features indicate that they are similar to mammalian exosomes (Rodrigues et al., 2008b; Casadevall et al., 2009).

Compositional analysis of $\mathrm{Hc}$ vesicles have revealed a very diverse pool of molecules. The lipid content included common components of biological membranes that can be involved in immune response, such as phosphatidylcholine, phosphatidylethanolamine, and phosphatidylserine (Gilbreath et al., 1986; Aramaki, 2000; Hoffmann et al., 2005; Albuquerque et al., 2008). In addition, 206 proteins were identified in $\mathrm{Hc}$ vesicles with a broad range of functions, such chaperones (Hsp30, Hsp70, and Hsp60), superoxide dismutase, catalase B, signal transduction proteins, vesicle formation, cell wall and cytoskeleton regulation, cell growth, and sugar, lipid, and amino acid metabolism (Albuquerque et al., 2008).

Hence, some proteins found in Hc vesicles are pathogenic determinants and/or are involved in host-pathogen interactions, so, hypothetically, the concentration of these molecules could provide an efficient release mechanism of virulence factors into host tissues and during infection could directly mediate host cell damage (Rodrigues et al., 2008b; Casadevall et al., 2009; Oliveira et al., 2010). In conclusion, Hc extracellular vesicle may function as "virulence bags," since virulence factors are concentrated within them and these molecules can modulate the host-pathogen interaction (Rodrigues et al., 2008b; Casadevall et al., 2009; Oliveira et al., 2010). In accord with this hypothesis, proteins extracted from $\mathrm{Hc}$ vesicles reacted with immune sera from patients with histoplasmosis, showing that vesicles can modulate the immune response (Albuquerque et al., 2008).

\section{CELL WALL PROTEINS}

The dynamic nature of the cell wall of Hc includes the changing composition of several proteins that participate in sensing the environment, modifying host-pathogen interactions, and defending the fungus against oxidative stress.

\section{Heat shock proteins}

Heat shock proteins (Hsps) are among the most evolutionary highly conserved proteins across all species (Lindquist, 1986). Hsps are essential for maintaining cellular functions, playing crucial roles in protein folding/unfolding, preventing aggregation of nascent polypeptides and toxicity by facilitating protein folding, directing assembly and disassembly of protein complexes, coordinating translocation/sorting of newly synthesized proteins into correct intracellular target compartments, degradation of aged/damaged proteins via the proteasome, regulating cell cycle and signaling, and also protecting cells against apoptosis ( $\mathrm{Li}$ and Srivastava, 2004; Saibil, 2008). As a key component of the heat shock response, Hsp expression is markedly upregulated when a cell is exposed to challenging conditions (e.g., high temperature, 
oxidative stress, radiation, inflammation, exposure to toxins, starvation, hypoxia, nitrogen deficiency, or water deprivation; Wu, 1995).

\section{Hsp60}

A Hsp of $60 \mathrm{kDa}(\mathrm{Hsp} 60)$ has been identified on the surface of $\mathrm{Hc}$, as well as within the cell and within vesicles. Hsp60 can be visualized as clusters on the cell wall by immunogold electron microscopy (Long et al., 2003). It appears to be the major ligand that mediates attachment of $\mathrm{Hc}$ to macrophage/monocyte CR3 integrin (CD11b/CD18; Long et al., 2003), resulting in phagocytosis (Long et al., 2003; Habich et al., 2006). Interestingly, a study of seven different Hsp60 species from microbes and mammals revealed that all proteins bound the CR3 receptor, although using different binding sites, and all elicited an inflammatory response in mouse macrophages (Habich et al., 2003). This implies the existence of distinct receptor structures responsible for Hsp60 binding and for Hsp60-induced release of pro-inflammatory mediators. In addition, the interaction of Hsp60 with immune cells exhibits immunoregulatory properties, controlling innate, and adaptive immune reactions (Habich and Burkart, 2007). Besides the interaction of Hsp60 from Hc with CR3 receptor complex on the cell surface of macrophages (Long et al., 2003), this protein could be interacting with other critical macrophages surface proteins, regulating the effector functions of these cells, or even exerting other important chaperonin-like functions that modify the pathogenesis of Hc (Guimaraes et al., 2011c).

Hsp60 from $\mathrm{Hc}$ is also an immunogenic molecule and has been described as a potential target for passive immunization therapy (Guimaraes et al., 2009, 2011a). Vaccination with Hc Hsp60 induces protection in a lethal murine infection model. The depletion of CD4+ cells during vaccination completely abolishes this protective effect (Gomez et al., 1995; Deepe and Gibbons, 2002). However, studies in the expressive phase of vaccination show that the elimination of CD4 $(+)$ or CD8 $(+)$ cells does not significantly modify fungal recovery from organs of infected animals or survival from a lethal challenge. Passive immunization with antibodies to Hsp60 offered protection against Hc, as mice treated with IgG1 or IgG2a mAbs to Hsp60 have significantly prolonged survival, with a reduction in the pulmonary and splenic CFUs after a week and a decrease up to 2.5 logs of yeast numbers in the lungs at 2 weeks (Guimaraes et al., 2009, 2011b).

Hsp60 expression levels are strain and temperature dependent, with an expression peak between 34 and $37^{\circ} \mathrm{C}$ (Shearer et al., 1987). The mechanism by which the heat shock response to environmental stressors occurs has not been fully elucidated. However, some evidence suggests that an increase in damaged or abnormal proteins activate Hsps (Santoro, 2000). Our group has shown that Hsp60 levels increase in response to temperature stress in both cytoplasm and cell wall subcellular fractions (Guimaraes et al., 2011c). However, Hsp60 cell wall levels was not significantly changed during heat shock, suggesting that in the conditions tested Hsp60 had a constitutive and regulatory function in the cell, orchestrating traffic of proteins to the cell surface where it is present at levels close to saturation, independent of overall expression in the cell.
The capacity of the Hsp60 to interact and work as a carrier molecule suggests innumerous regulatory functions of these proteins. Differential interactions have been dissected in both cytoplasmic and cell wall, and we identified common and unique interactions within each subcellular compartment (Guimaraes et al., 2011c). The interactome reveals that Hc Hsp60 engages nuclear chaperones, small chaperones, and Hsp90 families. Temperature increases interactions between Hsp60 and Hsp70 in the cell wall. Furthermore, cell wall Hsp60 more broadly interacts with enzymes related to carbohydrate metabolism, suggesting a trafficking function of Hsp60 related to enhanced energy acquisition under stress conditions. Additionally, Hsp60 apparently contributes with cell wall changes that allow the pathogen to survive under stress conditions (Shaner et al., 2008). Hence, this protein participates as a key regulator of diverse cellular processes, including amino acid, protein, lipid, and carbohydrate metabolism, cell signaling, replication, and expression of virulence associated proteins.

\section{Hsp70}

Hsp70 is a putative chaperone secreted by $\mathrm{Hc}$ to the extracellular milieu, probably within vesicles (Albuquerque et al., 2008), but also found on the cellular surface of the fungus (Gomez et al., 1992, 1997; Lopes et al., 2010). Little is known about the function of this protein in Hc. Recombinant Hc Hsp70 elicits a cutaneous delayed-type hypersensitive response in mice. However, vaccination with Hsp70 did not confer protection against $\mathrm{Hc}$ infection (Allendoerfer et al., 1996). Hc Hsps, such as Hsp70 and Hsp82 (an Hsp recently associated with virulence, albeit by unknown mechanisms (Edwards et al., 2011), display a similar expression pattern to Hsp60 (Caruso et al., 1987; Minchiotti et al., 1992). Hsp70 is highly expressed by the fungus when undergoing transition from mycelium-to-yeast (Kamei et al., 1992) and it is also strain and temperature dependent, having its peak of expression at $37^{\circ} \mathrm{C}$ (Shearer et al., 1987). Hsp70 synthesis increases soon after heat shock (Lambowitz et al., 1983; Shearer et al., 1987) and we demonstrated more interactions between Hsp70 and Hsp60 at elevated temperatures. Thus, Hc Hsp70 interacts with Hsp60, in various cellular compartments, and might communicate with other intracellular chaperones, composing a heat shock regulon complex.

\section{M antigen}

The $\mathrm{M}$ antigen is the major diagnostic antigen of $\mathrm{Hc}$ as elicits intense humoral and cellular immune responses (Hamilton et al., 1990; Deepe, 1994; Deepe and Durose, 1995; Hamilton, 1998; Zancopé-Oliveira et al., 1999; Guimaraes et al., 2006). Antibodies to $M$ antigen appear soon after infection and, importantly, antibodies to $\mathrm{M}$ antigen can indicate prior exposure, acute disease or a chronic progressive disease. The $\mathrm{M}$ precipitin reaction can persist for up to 3 years after disease resolution and people who have never had contact with Hc can become reactive after skin testing with histoplasmin (Klite, 1965; Kaufman, 1992).

Based on its amino acid sequence and cross reactivity of mAbs raised against the $\mathrm{M}$ antigen with other fungal catalases, the $\mathrm{M}$ protein has been characterized as a B catalase (Hamilton et al., 1990; Zancopé-Oliveira et al., 1999). The M antigen has been detected in cell-free extracts and in solution after permeabilizing Hc yeast, 
suggesting that the $M$ antigen is a secreted enzyme (Howard, 1983). $\mathrm{Hc}$ expresses two other catalases, CatP, and CatA, both located intracellularly, and all of these proteins are involved in detoxification of reactive oxygen species generated by fungal metabolism and respiration (Johnson et al., 2002).

Our group sought to further characterize the $\mathrm{M}$ antigen and confirm its catalase activity. Initially, we constructed a 3$\mathrm{D}$ rendering by homology modeling, and found structures and domains that closely resembled characterized catalases. Specific mAbs against recombinant $\mathrm{M}$ antigen labeled the yeast cell surface of $\mathrm{Hc}$ and provided a single band in immunoblots using cell wall/membrane preparations. Hence, these mAbs further confirmed the cell surface location of the M antigen. Additionally, we demonstrated that the majority of catalase activity was concentrated in fungal surface preparations. The localization of the $\mathrm{M}$ antigen to the cell surface makes the $\mathrm{M}$ antigen the most important catalase for detoxification of host derived peroxides, protecting the fungus against oxidative stress, and also makes this protein accessible to host immune cells and antibody (Guimaraes et al., 2008). However, its importance during establishment of infection and as a vaccine candidate awaits characterization.

\section{H antigen}

The $\mathrm{H}$ antigen has been described as a secreted component of histoplasmin, the most important immunodiagnostic reagent of Hc obtained from culture supernatant of the filamentous culture of the fungus (Ehrhard and Pine, 1972a,b; Zancope-Oliveira et al., 1994; Guimaraes et al., 2006). This antigen consistently reacts with sera from histoplasmosis patient, and antibodies to the $\mathrm{H}$ antigen may be detected 1-2 years after the resolution of acute disease. Antibodies to the $\mathrm{H}$ antigen usually disappear more quickly than the anti-M antibodies (Davies, 1986). The H precipitin rarely is detected after HMIN skin testing.

Although this protein has been extensively studied as an immunodiagnostic reagent for more than 50 years, its biological function has not been precisely elucidated. The deduced amino acid sequence of the $\mathrm{H}$ gene displays homology to secreted fungal $\beta$-glucosidases and has a molecular weight from 108 to $120 \mathrm{kDa}$. However, recombinant protein expressed in a prokaryotic host (Fisher et al., 1999) did not demonstrate $\beta$-glucosidase enzymatic activity, probably due to incorrect folding and altered protein structure. Subsequently, expression in the native organism has resulted in production of a full-size, glycosylated $\mathrm{H}$ antigen with functional $\beta$-glucosidase activity (Fisher et al., 1999). Potential biological activities for this enzyme include nutrient acquisition (by the breakdown of environmental cellulosic or carbohydrate substrates to acquire glucose; Woodward and Wiseman, 1982) or modulation of cell wall architecture (Deepe and Durose, 1995; Fisher et al., 1999; Fisher and Woods, 2000; by the breakdown of cell wall polymers and carbohydrates; Kruse and Cole, 1992; Akiyama et al., 1998).

Recombinant $\mathrm{H}$ antigen can stimulate splenocytes from mice immunized with viable yeast or with antigen suspended in adjuvant (Deepe and Durose, 1995; Deepe and Gibbons, 2001). However, despite stimulating a cell-mediated immune response, vaccination with the antigen was not able to protect against either a lethal or a sub-lethal intravenous inoculum of yeast (Deepe and
Durose, 1995). Interestingly, vaccination with $\mathrm{H}$ antigen protected mice in a pulmonary histoplasmosis model (Deepe and Gibbons, 2001). The protective immunization was associated with production of IFN- $\gamma$, granulocyte-macrophage colony-stimulating factor (GM-CSF), interleukin-4 (IL-4), and interleukin-10 (IL10) by splenocytes and in parallel, there was major expansion of $\mathrm{CD}^{+}$or $\mathrm{CD}^{+}$cells in spleens of mice (Deepe and Gibbons, 2001).

\section{Histone 2B}

Histones are proteins commonly associated with DNA and have high conserved structure and functions. Although they are classically located in the nucleus, cell surface histones have been described in both eukaryotic and prokaryotic organisms. Histones have been described in the plasma membrane of leukocytes (Rekvig et al., 1987), T cells (functioning as proteoglycan receptors; Ojcius et al., 1991; Khan et al., 1998), B cells (Mecheri et al., 1993), and a human lung carcinoma cell line (as an adhesin to the extracellular matrix; Bilozur and Biswas, 1990). A histone 2B of Mycobacterium leprae can be located on the bacterial cell surface and this expressed protein facilitates invasion of Schwann cells (Shimoji et al., 1999; De Melo Marques et al., 2000) by binding laminin on peripheral nerves (Pessolani et al., 1993; De Melo Marques et al., 2000). Similarly Mycobacterium smegmatis binds to laminin on human pneumocytes and macrophages through a histone-like protein located on its surface (Pethe et al., 2001). We have described a histone $2 \mathrm{~B}-$ like protein of $17-\mathrm{kDa}$ antigen expressed on the surface of $\mathrm{Hc}$, and it is speculated that the protein is important in cell-cell signaling and modulation of the immune response by the fungus (Nosanchuk et al., 2003).

Administration of mAbs that bind histone $2 \mathrm{~B}$-like protein on the surface of $\mathrm{Hch}$ has been shown to reduce fungal burden, decrease pulmonary inflammation, and prolong survival in a murine infection model (Nosanchuk, 2005). The protective response mediated by these mAbs was associated with enhanced levels of IL-4, IL6 , and IFN- $\gamma$ in the lungs of infected mice. The mAbs increased phagocytosis of yeast by J774.16 cells through a CR3-dependent process and uptake of the opsonized yeast was associated with yeast growth inhibition and killing (Nosanchuk et al., 2003; Nosanchuk, 2005). The altered intracellular fate of the opsonized Hc yeast was characterized by significantly enhanced macrophage phagosome activation and maturation and also a reduced ability of the organism to regulate the phagosomal $\mathrm{pH}$. Opsonization also increased antigen processing and reduced negative PD-1/PDL-1 co-stimulation in macrophages, resulting in more-efficient T-cell activation (Shi et al., 2008).

\section{YPS3}

YPS3 is both resident in the cell wall and released in significant quantities into the culture medium during growth of Hc. This protein is expressed only by the pathogenic yeast phase in vitro or infecting tissues (Bohse and Woods, 2005). The yps3 locus is present in all the strains of $\mathrm{Hc}$, but protein production seems to be limited to the North American restriction fragment length polymorphism class 2/NAm 2 group of strains (Bohse and Woods, 2007b). These strains have the highest virulence among all the 
Hc isolates and the expression of Yps3 is likely associated with increased virulence (Bohse and Woods, 2005). The Yps3 protein in the NAm 2 strains has an average length of 137 amino acids. However, intragenic hypervariable region of tandem repeats in the $y p s 3$ gene might result in different size fluctuation or protein isoforms among Hc strains (Bohse and Woods, 2007a). Another important feature of this protein is the presence of an $\mathrm{N}$-terminal secretion signal sequence (Bohse and Woods, 2005). As this protein is secreted by the yeast, it binds to the polysaccharide chitin and becomes exposed on the cell wall.

Intriguingly, silencing of the YPS3 transcript did not result in any detectable phenotypic differences in vitro (Bohse and Woods, $2007 \mathrm{~b}$ ). Silenced yeast displayed normal growth at $37^{\circ} \mathrm{C}$ and similar virulence to wild-type yeasts in co-cultures with a RAW 264.7 murine macrophage-like cell line. However, in an in vivo murine infection model, silenced yeast caused significantly less disease than wild-type yeast. Reductions in fungal burden were particularly evident in phagocyte-rich tissues, such spleen and liver. Hence, YPS3 is clearly linked to Hc virulence in vivo.

\section{MELANIN}

Many pathogenic fungi produce the enigmatic polymer pigment melanin in their cell wall (Nosanchuk and Casadevall, 2006). $\mathrm{Hc}$ is also able to synthesize melanin, on both conidia and yeast (Nosanchuk et al., 2002). Melanins are negatively charged, hydrophobic pigments of high molecular weight, formed by the oxidative polymerization of exogenous phenolic and/or indolic compounds. Since Hc conidia synthesize melanin in the absence of exogenous phenolic substrate, it is probable that conidia are melanized in the environment (Nosanchuk et al., 2002). Thus, melanization may protect the conidia from environmental insults, such as damage by solar UV radiation, extreme temperatures and

\section{REFERENCES}

Ajello, L. (1971). Coccidioidomycosis and histoplasmosis. A review of their epidemiology and geographical distribution. Mycopathol. Mycol. Appl. 45, 221-230.

Akiyama, T., Kaku, H., and Shibuya, N. (1998). A cell wall-bound betaglucosidase from germinated rice: purification and properties. Phytochemistry 48, 49-54.

Albuquerque, P. C., Nakayasu, E. S., Rodrigues, M. L., Frases, S., Casadevall, A., Zancope-Oliveira, R. M., Almeida, I. C., and Nosanchuk, J. D. (2008). Vesicular transport in Histoplasma capsulatum: an effective mechanism for trans-cell wall transfer of proteins and lipids in ascomycetes. Cell. Microbiol. 10, 1695-1710.

Allendoerfer, R., Biovin, G. P., and Deepe, G. S. Jr. (1997). Modulation of immune responses in murine pulmonary histoplasmosis. J. Infect. Dis. 175, 905-914.

Allendoerfer, R., Maresca, B., and Deepe, G. S. Jr. (1996). Cellular immune responses to recombinant heat shock protein 70 from Histoplasma capsulatum. Infect. Immun. 64, 4123-4128.

Alteras, I. (1966). First Romanian isolation of Histoplasma capsulatum from the soil. Dermatol. Int. 5, 69-71.

Anjos, A. R., Calvi, S. A., Ferracini, R., Peracoli, M. T., Silva, C. L., and Soares, A. M. (2002). Role of Paracoccidioides brasiliensis cell wall fraction containing beta-glucan in tumor necrosis factor-alpha production by human monocytes: correlation with fungicidal activity. Med. Mycol. 40, 377-382.

Aramaki, Y. (2000). Liposomes as immunomodulator - inhibitory effect of liposomes on NO production from macrophages. Biol. Pharm. Bull. 23, 1267-1274.

Azuma, I., Kanetsuna, F., Tanaka, Y., Yamamura, Y., and Carbonell, L. M. (1974). Chemical and immunological properties of galactomannans obtained from Histoplasma duboisii, ioides brasiliensis and Blastomyces dermatitidis. Mycopathol. Mycol. Appl. 54, 111-125. L. (1984). Carbohydrate structures Histoplasma capsulatum, Paracoccid-

Barr, K., Laine, R. A., and Lester, R.

chemical (heavy metals and oxidizing agents Nosanchuk et al., 2002) and also predation in the environment, against free radicals, defensins, and other toxic responses within a host. Melanization reduces Hc susceptibility to host defense mechanisms and antifungal drugs (Van Duin et al., 2002; Taborda et al., 2008). Moreover, melanization of $\mathrm{Hc}$ protects the fungus against chemotherapy with amphotericin B or echinocandins (Van Duin et al., 2002; Gomez and Nosanchuk, 2003). Hence, Hc cell wall melanin protects the fungus from a myriad of insults and the polymeric nature of the pigment enhances its structural strength. Moreover, yeast melanization appears to play important roles in virulence and pathogenicity.

\section{CONCLUSION}

The fungal cell wall is fundamentally the structure that interacts with environmental and host milieus. A current model for the Hc cell wall is presented on the Figure 2. It provides structural support, varying from flexible to a rigid structure, and protects the cell against environmental stressors and host anti-microbial effectors mechanisms. Many fungal antigens are conserved among phylogenetically related species and many that are associated with virulence can be found on their cell walls. Hence, common targets could be used to induce protection against different fungal species described (Casadevall and Pirofski, 2007). Although approaches to developing protective responses vary from vaccination with cells or recombinant antigens to passive protection with mAbs, coordinating knowledge across the fungal pathogens may lead to new, more effective means for combating potentially lethal mycoses. In this survey of Hc surface structures, we demonstrate the function of diverse antigens in regulating Hc biology and discuss the current knowledge base from which we can build upon in future investigations.

of three novel phosphoinositolcontaining sphingolipids from the yeast Histoplasma capsulatum. Biochemistry 23, 5589-5596.

Barr, K., and Lester, R. L. (1984). Occurrence of novel antigenic phosphoinositol-containing sphingolipids in the pathogenic yeast Histoplasma capsulatum. Biochemistry 23, 5581-5588.

Barreto-Bergter, E., Pinto, M. R., and Rodrigues, M. L. (2004). Structure and biological functions of fungal cerebrosides. An. Acad. Bras. Cienc. 76, 67-84.

Berliner, M. D. (1973). Histoplasma capsulatum: vital staining for the differentiation of the albino and brown phenotypes in vitro. Sabouraudia 11, 271-273.

Bernard, M., and Latge, J. P. (2001). Aspergillus fumigatus cell wall: composition and biosynthesis. Med. Mycol. 39 (Suppl. 1), 9-17.

Bilozur, M. E., and Biswas, C. (1990). Identification and characterization of heparan sulfate-binding proteins from human lung carcinoma cells. J. Biol. Chem. 265, 19697-19703.
Bittencourt, V. C., Figueiredo, R. T., Da Silva, R. B., Mourao-Sa, D. S., Fernandez, P. L., Sassaki, G. L., Mulloy, B., Bozza, M. T., and Barreto-Bergter, E. (2006). An alphaglucan of Pseudallescheria boydii is involved in fungal phagocytosis and Toll-like receptor activation. J. Biol. Chem. 281, 22614-22623.

Bohse, M. L., and Woods, J. P. (2005). Surface localization of the Yps $3 p$ protein of Histoplasma capsulatum. Eukaryot. Cell 4, 685-693.

Bohse, M. L., and Woods, J. P. (2007a). Expression and interstrain variability of the YPS3 gene of Histoplasma capsulatum. Eukaryot. Cell 6, 609-615.

Bohse, M. L., and Woods, J. P. (2007b). RNA interference-mediated silencing of the YPS3 gene of Histoplasma capsulatum reveals virulence defects. Infect. Immun. 75, 2811-2817.

Borelli, D. (1970). Prevalence of systemic mycosis in Latin America. Proc. Int. Symp. Mycoses Scient. Publ. 205.

Bradsher, R. W. (1996). Histoplasmosis and blastomycosis. Clin. Infect. Dis 22(Suppl. 2), S102-S111. 
Bromuro, C., Romano, M., Chiani, P., Berti, F., Tontini, M., Proietti, D., Mori, E., Torosantucci, A., Costantino, P., Rappuoli, R., and Cassone, A. (2010). Beta-glucan-CRM197 conjugates as candidates antifungal vaccines. Vaccine 28, 2615-2623.

Brown, G. D. (2006). Dectin-1: a signalling non-TLR patternrecognition receptor. Nat. Rev. Immunol. 6, 33-43.

Bulawa, C. E., Miller, D. W., Henry, L. K., and Becker, J. M. (1995). Attenuated virulence of chitindeficient mutants of Candida albicans. Proc. Natl. Acad. Sci. U.S.A. 92, 10570-10574.

Cambi, A., Gijzen, K., De Vries, J. M., Torensma, R., Joosten, B., Adema, G. J., Netea, M. G., Kullberg, B. J., Romani, L., and Figdor, C. G. (2003). The C-type lectin DC-SIGN (CD209) is an antigen-uptake receptor for Candida albicans on dendritic cells. Eur. J. Immunol. 33, 532-538.

Cano, M. V., and Hajjeh, R. A. (2001). The epidemiology of histoplasmosis: a review. Semin. Respir. Infect. 16, 109-118.

Caruso, M., Sacco, M., Medoff, G., and Maresca, B. (1987). Heat shock 70 gene is differentially expressed in Histoplasma capsulatum strains with different levels of thermotolerance and pathogenicity. Mol. Microbiol. 1, 151-158.

Casadevall, A., Nosanchuk, J. D., Williamson, P., and Rodrigues, M. L. (2009). Vesicular transport across the fungal cell wall. Trends Microbiol. $17,158-162$.

Casadevall, A., and Pirofski, L. A. (2007). Antibody-mediated protection through cross-reactivity introduces a fungal heresy into immunological dogma. Infect. Immun. 75, 5074-5078.

Cash, H. L., Whitham, C. V., and Hooper, L. V. (2006). Refolding, purification, and characterization of human and murine RegIII proteins expressed in Escherichia coli. Protein Expr. Purif. 48, 151-159.

Couto, M. A., Liu, L., Lehrer, R. I., and Ganz, T. (1994). Inhibition of intracellular Histoplasma capsulatum replication by murine macrophages that produce human defensin. Infect. Immun. 62, 2375-2378.

Cox, R. A., and Best, G. K. (1972). Cell wall composition of two strains of Blastomyces dermatitidis exhibiting differences in virulence for mice. Infect. Immun. 5 449-453.

Csillag, A., and Wermer, T. (1956). Histoplasmosis. Orv. Hetil. 97, 964-967.

Da Silva, A. F., Rodrigues, M. L., Farias, S. E., Almeida, I. C.,
Pinto, M. R., and Barreto-Bergter, E. (2004). Glucosylceramides in Colletotrichum gloeosporioides are involved in the differentiation of conidia into mycelial cells. FEBS Lett. 561, 137-143.

Davies, S. F. (1986). Serodiagnosis of histoplasmosis. Semin. Respir. Infect. 1, 9-15.

Davies, S. F., Khan, M., and Sarosi, G. A. (1978). Disseminated histoplasmosis in immunologically suppressed patients. Occurrence in a nonendemic area. Am. J. Med. 64, 94-100.

Davis, T. E. Jr., Domer, J. E., and Li, Y. T. (1977). Cell wall studies of Histoplasma capsulatum and Blastomyces dermatitidis using autologous and heterologous enzymes. Infect. Immun. 15, 978-987.

De Melo Marques, M. A., Mahapatra, S., Nandan, D., Dick, T., Sarno, E. N., Brennan, P. J., and Vidal Pessolani, M. C. (2000). Bacterial and host-derived cationic proteins bind alpha2-laminins and enhance Mycobacterium leprae attachment to human Schwann cells. Microbes Infect. 2, 1407-1417.

Deepe, G. S. Jr. (2005). Modulation of infection with Histoplasma capsulatum by inhibition of tumor necrosis factor-alpha activity. Clin. Infect. Dis. 41(Suppl. 3), S204-S207.

Deepe, G. S. Jr., and Durose, G. G. (1995). Immunobiological activity of recombinant $\mathrm{H}$ antigen from Histoplasma capsulatum. Infect. Immun. 63, 3151-3157.

Deepe, G. S. Jr., and Gibbons, R. (2001). Protective efficacy of $\mathrm{H}$ antigen from Histoplasma capsulatum in a murine model of pulmonary histoplasmosis. Infect. Immun. 69, 3128-3134.

Deepe, G. S. Jr., Gibbons, R. S., and Smulian, A. G. (2008). Histoplasma capsulatum manifests preferential invasion of phagocytic subpopulations in murine lungs. J. Leukoc. Biol. 84, 669-678.

Deepe, G. S. Jr., Smelt, S., and Louie, J. S. (2005). Tumor necrosis factor inhibition and opportunistic infections. Clin. Infect. Dis. 41(Suppl. 3), S187-S188.

Deepe, G. S. J., and Gibbons, R. S. (2002). Cellular and molecular regulation of vaccination with heat shock protein 60 from Histoplasma capsulatum. Infect. Immun. 70, 3759-3767.

Deepe, G. S. Jr. (1994). The immune response to Histoplasma capsulatum: unearthing its secrets. J. Lab. Clin. Med. 123, 201-205.

Dennehy, K. M., and Brown, G. D. (2007). The role of the beta-glucan receptor Dectin-1 in control of fungal infection. J. Leukoc. Biol. 82, 253-258.

Dickson, R. C., and Lester, R. L. (1999). Yeast sphingolipids. Biochem. Biophys. Acta 1426, 347-357.

Disalvo, A. F., Bigler, W. J., Ajello, L., Johnson, J. E., and Palmer, J. (1970). Bat and soil studies for sources of histoplasmosis in Florida. Public. Health. Rep. 85, 1063-1069.

Domer, J. E. (1971). Monosaccharide and chitin content of cell walls of Histoplasma capsulatum and Blastomyces dermatitidis. J. Bacteriol. 107, 870-877.

Domer, J. E., Hamilton, J. G., and Harkin, J. C. (1967). Comparative study of the cell walls of the yeastlike and mycelial phases of Histoplasma capsulatum. J. Bacteriol. 94, 466-474.

Duarte-Escalante, E., Zenteno, E., and Taylor, M. L. (2003). Interaction of Histoplasma capsulatum yeasts with galactosylated surface molecules of murine macrophages. Arch. Med. Res. 34, 176-183.

Edwards, J. A., Zemska, O., and Rappleye, C. A. (2011). Discovery of a Role for Hsp82 in Histoplasma virulence through a quantitative screen for macrophage lethality. Infect. Immun. 79, 3348-3357.

Edwards, M. R., Hazen, E. L., and Edwards, G. A. (1960). The micromorphology of the tuberculate spores of Histoplasma capsulatum. Can. J. Microbiol. 6, 65-70.

Ehrhard, H. B., and Pine, L. (1972a). Factors influencing the production of $\mathrm{H}$ and $\mathrm{M}$ antigens by Histoplasma capsulatum: development and evaluation of a shake culture. Appl. Microbiol. 23, 236-249.

Ehrhard, H. B., and Pine, L. (1972b). Factors influencing the production of $\mathrm{H}$ and $\mathrm{M}$ antigens by Histoplasma capsulatum: effect of physical factors and composition of medium. Appl. Microbiol. 23, 250-261.

Eissenberg, L. G., and Goldman, W. E. (1987). Histoplasma capsulatum fails to trigger release of superoxide from macrophages. Infect. Immun. 55, 29-34.

Eissenberg, L. G., and Goldman, W. E. (1991). Histoplasma variation and adaptive strategies for parasitism: new perspectives on histoplasmosis. Clin. Microbiol. Rev. 4, 411-421.

Eissenberg, L. G., Moser, S. A., and Goldman, W. E. (1997). Alterations to the cell wall of Histoplasma capsulatum yeasts during infection of macrophages or epithelial cells. J. Infect. Dis. 175, 1538-1544.

Eissenberg, L. G., Poirier, S., and Goldman, W. E. (1996). Phenotypic variation and persistence of Histoplasma capsulatum yeasts in host cells. Infect. Immun. 64, 5310-5314.

Emmons, C. W. (1950). Histoplasmosis: animal reservoirs and other sources in nature of the pathogenic fungus Histoplasma capsulatum. Am. J. Public Health 40, 436-440.

Emmons, C. W. (1956a). Histoplasmosis in animals. Public Health Monogr. 70, 272-273.

Emmons, C. W. (1956b). Isolation of Histoplasma capsulatum from soil. Public Health Monogr. 70, 237-239.

Emmons, C. W., Klite, P. D., Baer, G. M., and Hill, W. B. Jr. (1966). Isolation of Histoplasma capsulatum from bats in the United States. Am. J. Epidemiol. 84, 103-109.

Figueiredo, F., Alves, L. M., and Silva, C. L. (1993). Tumour necrosis factor production in vivo and in vitro in response to Paracoccidioides brasiliensis and the cell wall fractions thereof. Clin. Exp. Immunol. 93, 189-194.

Fisher, K. L., Deepe, G. S. Jr., and Woods, J. P. (1999). Histoplasma capsulatum strain variation in both $\mathrm{H}$ antigen production and betaglucosidase activity and overexpression of HAG1 from a telomeric linear plasmid. Infect. Immun. 67, 3312-3316.

Fisher, K. L., and Woods, J. P. (2000). Determination of beta-glucosidase enzymatic function of the Histoplasma capsulatum $\mathrm{H}$ antigen using a native expression system. Gene 247, 191-197.

Garrison, R. G., and Boyd, K. S. (1977). The fine structure of microconidial germination and vegetative cells of Histoplasma capsulatum. Ann. Microbiol. (Paris) 128, 135-149.

Gilbreath, M. J., Hoover, D. L., Alving, C. R., Swartz, G. M. Jr., and Meltzer, M. S. (1986). Inhibition of lymphokineinduced macrophage microbicidal activity against Leishmania major by liposomes: characterization of the physicochemical requirements for liposome inhibition. J. Immunol. 137, 1681-1687.

Gomez, B. L., Figueroa, J. I., Hamilton, A. J., Ortiz, B. L., Robledo, M. A., Restrepo, A., and Hay, R. J. (1997). Development of a novel antigen detection test for histoplasmosis. J. Clin. Microbiol. 35, 2618-2622.

Gomez, B. L., and Nosanchuk, J. D. (2003). Melanin and fungi. Curr. Opin. Infect. Dis. 16, 91-96.

Gomez, F. J., Allendoerfer, R., and Deepe, G. S. Jr. (1995). Vaccination with recombinant heatshock protein 60 from Histoplasma capsulatum. Infect. Immun. 63, 2587-2595. 
Gomez, F. J., Gomez, A. M., and Deepe, G. S. Jr. (1992). An 80-kilodalton antigen from Histoplasma capsulatum that has homology to heat shock protein 70 induces cell-mediated immune responses and protection in mice. Infect. Immun. 60, 2565-2571.

Goodwin, R. A. Jr., and Des Prez, R. M. (1978). State of the art: histoplasmosis. Am. Rev. Respir. Dis. 117, 929-956.

Goodwin, R. A., Loyd, J. E., and Des Prez, R. M. (1981). Histoplasmosis in normal hosts. Medicine (Baltimore) 60, 231-266.

Gorocica, P., Taylor, M. L., AlvaradoVasquez, N., Perez-Torres, A., Lascurain, R., and Zenteno, E. (2009). The interaction between Histoplasma capsulatum cell wall carbohydrates and host components: relevance in the immunomodulatory role of histoplasmosis. Mem. Inst. Oswaldo Cruz 104, 492-496.

Guimaraes, A. J., Frases, S., Gomez, F. J., Zancope-Oliveira, R. M., and Nosanchuk, J. D. (2009). Monoclonal antibodies to heat shock protein 60 alter the pathogenesis of Histoplasma capsulatum. Infect. Immun. 77, 1357-1367.

Guimaraes, A. J., Hamilton, A. J., De, M. G. H. L., Nosanchuk, J. D., and Zancope-Oliveira, R. M. (2008). Biological function and molecular mapping of $\mathrm{M}$ antigen in yeast phase of Histoplasma capsulatum. PLoS ONE 3, e3449. doi:10.1371/journal.pone.0003449.g001

Guimaraes, A. J., Frases, S., Pontes, B., De Cerqueira, M. D., Rodrigues, M. L., Viana, N. B., Nimrichter, L., and Nosanchuk, J. D. (2011a). Agglutination of Histoplasma capsulatum by IgG monoclonal antibodies against Hsp60 impacts macrophage effector functions. Infect. Immun. 79, 918-927.

Guimaraes, A. J., Martinez, L. R., and Nosanchuk, J. D. (2011b). Passive administration of monoclonal antibodies against $H$. capsulatum and other fungal pathogens. J. Vis. Exp. doi: $10.3791 / 2532$.

Guimaraes, A. J., Nakayasu, E. S., Sobreira, T. J., Cordero, R. J., Nimrichter, L., Almeida, I. C., and Nosanchuk, J. D. (2011c). Histoplasma capsulatum heat-shock 60 orchestrates the adaptation of the fungus to temperature stress. PLoS ONE 6, e14660. doi:10.1371/journal.pone. 0014660

Guimaraes, A. J., Nosanchuk, J. D., and Zancope-Oliveira, R. M. (2006). Diagnosis of Histoplasmosis. Braz. J. Microbiol. 37, 1-13.

Habich, C., and Burkart, V. (2007). Heat shock protein 60: regulatory role on innate immune cells. Cell. Mol. Life Sci. 64, 742-751.

Habich, C., Kempe, K., Gomez, F. J., Lillicrap, M., Gaston, H., Van Der Zee, R., Kolb, H., and Burkart, V. (2006). Heat shock protein 60: identification of specific epitopes for binding to primary macrophages. FEBS Lett. 580, 115-120.

Habich, C., Kempe, K., Van Der Zee, R., Burkart, V., and Kolb, H. (2003). Different heat shock protein 60 species share pro-inflammatory activity but not binding sites on macrophages. FEBS Lett. 533, 105-109.

Hamilton, A. J. (1998). Serodiagnosis of histoplasmosis, paracoccidioidomycosis and penicilliosis marneffei; current status and future trends. Med. Mycol. 36, 351-364.

Hamilton, A. J., Bartholomew, M. A., Figueroa, J., Fenelon, L. E., and Hay, R. J. (1990). Evidence that the M antigen of Histoplasma capsulatum var. capsulatum is a catalase which exhibits cross-reactivity with other dimorphic fungi. J. Med. Vet. Mycol. 28, 479-485.

Hay, R. J. (1992). Laboratory techniques in the investigation of fungal infections. Genitourin. Med. 68, 409-412.

Hoffmann, P. R., Kench, J. A., Vondracek, A., Kruk, E., Daleke, D. L., Jordan, M., Marrack, P., Henson, P. M., and Fadok, V. A. (2005). Interaction between phosphatidylserine and the phosphatidylserine receptor inhibits immune responses in vivo. J. Immunol. 174, 1393-1404.

Hogan, L. H., and Klein, B. S. (1994). Altered expression of surface alpha-1,3-glucan in genetically related strains of Blastomyces dermatitidis that differ in virulence. Infect. Immun. 62, 3543-3546.

Howard, D. H. (1983). Studies on the catalase of Histoplasma capsulatum. Infect. Immun. 39, 1161-1166.

Isbister, J., Elliott, M., and Nogrady, S. (1976). Histoplasmosis: an outbreak occurring among young men who visited one cave. Med. J. Aust. 2, 243-248.

Johnson, C. H., Klotz, M. G., York, J. L., Kruft, V., and Mcewen, J. E. (2002). Redundancy, phylogeny and differential expression of Histoplasma capsulatum catalases. Microbiology 148, 1129-1142.

Kamei, K., Brummer, E., Clemons, K. V., and Stevens, D. A. (1992). Induction of stress protein synthesis in Histoplasma capsulatum by heat, low $\mathrm{pH}$ and hydrogen peroxide. J. Med. Vet. Mycol. 30, 385-393.

Kanetsuna, F. (1981). Ultrastructural studies on the dimorphism of Paracoccidioides brasiliensis, Blastomyces dermatitidis and Histoplasma capsulatum. Sabouraudia 19, 275-286.

Kanetsuna, F., Carbonell, L. M., Azuma, I., and Yamamura, Y. (1972). Biochemical studies on the thermal dimorphism of Paracoccidioides brasiliensis. J. Bacteriol. 110, 208-218.

Kanetsuna, F., Carbonell, L. M., Gil, F., and Azuma, I. (1974). Chemical and ultrastructural studies on the cell walls of the yeastlike and mycelial forms of Histoplasma capsulatum. Mycopathol. Mycol. Appl. 54, 1-13.

Kataoka, K., Muta, T., Yamazaki, S. and Takeshige, K. (2002). Activation of macrophages by linear (1right-arrow3)-beta-D-glucans. Impliations for the recognition of fungi by innate immunity. J. Biol. Chem. 277, 36825-36831.

Kauffman, C. A. (2007). Histoplasmosis: a clinical and laboratory update. Clin. Microbiol. Rev. 20, 115-132.

Kaufman, L. (1992). Laboratory methods for the diagnosis and confirmation of systemic mycoses. Clin. Infect. Dis. 14(Suppl. 1), S23-S29.

Khan, I. U., Wallin, R., Gupta, R. S., and Kammer, G. M. (1998). Protein kinase A-catalyzed phosphorylation of heat shock protein 60 chaperone regulates its attachment to histone $2 \mathrm{~B}$ in the $\mathrm{T}$ lymphocyte plasma membrane. Proc. Natl. Acad. Sci. U.S.A. 95, 10425-10430.

Klimpel, K. R., and Goldman, W. E. (1988). Cell walls from avirulent variants of Histoplasma capsulatum lack alpha-(1,3)-glucan. Infect. Immun. 56, 2997-3000.

Klite, P. D. (1965). The interpretation of agar-gel precipitin reactions in histoplasmosis. J. Lab. Clin. Med. 66, 770-787.

Koppel, E. A., Van Gisbergen, K. P., Geijtenbeek, T. B., and Van Kooyk, Y. (2005). Distinct functions of DC-SIGN and its homologues L-SIGN (DC-SIGNR) and mSIGNR1 in pathogen recognition and immune regulation. Cell. Microbiol. 7, 157-165.

Kruse, D., and Cole, G. T. (1992). A seroreactive 120-kilodalton beta1,3-glucanase of Coccidioides immitis which may participate in spherule morphogenesis. Infect. Immun. 60 4350-4363.

Kugler, S., Schurtz Sebghati, T., Groppe Eissenberg, L., and Goldman, W. E. (2000). Phenotypic variation and intracellular parasitism by Histoplasma capsulatum. Proc. Natl. Acad. Sci. U.S.A. 97, 8794-8798.

Kwon-Chung, K. J. (1972). Sexual stage of Histoplasma capsulatum. Science 175, 326.
Kwon-Chung, K. J. (1975). Perfect state (Emmonsiella capsulata) of the fungus causing large-form African histoplasmosis. Mycologia 67, 980-990.

Kwon-Chung, K. J., and Bennett, J. E. (1992). Medical Mycology. Philadelphia: Lea \& Febiger.

Lambowitz, A. M., Kobayashi, G. S., Painter, A., and Medoff, G. (1983). Possible relationship of morphogenesis in pathogenic fungus, Histoplasma capsulatum, to heat shock response. Nature 303, 806-808.

Li, Z., and Srivastava, P. (2004). Heat-shock proteins. Curr. Protoc. Immunol. Appendix 1, Appendix 1T.

Limaye, A. P., Connolly, P. A., Sagar, M., Fritsche, T. R., Cookson, B. T., Wheat, L. J., and Stamm, W. E. (2000). Transmission of Histoplasma capsulatum by organ transplantation. N. Engl. J. Med. 343, 1163-1166.

Lindquist, S. (1986). The heat-shock response. Annu. Rev. Biochem. 55, 1151-1191.

Lipke, P. N., and Ovalle, R. (1998). Cell wall architecture in yeast: new structure and new challenges. J. Bacteriol. 180, 3735-3740.

Londero, A. T., and Ramos, C. D. (1978). The status of histoplasmosis in Brazil. Mycopathologia 64, 153-156.

Long, K. H., Gomez, F. J., Morris, R. E., and Newman, S. L. (2003). Identification of heat shock protein 60 as the ligand on Histoplasma capsulatum that mediates binding to CD18 receptors on human macrophages. J. Immunol. 170, 487-494.

Lopes, L. C., Guimaraes, A. J., De Cerqueira, M. D., Gomez, B. L., and Nosanchuk, J. D. (2010). A Histoplasma capsulatum-specific IgG1 isotype monoclonal antibody, $\mathrm{H} 1 \mathrm{C}$, to a 70-kilodalton cell surface protein is not protective in murine histoplasmosis. Clin. Vaccine Immunol. 17, 1155-1158.

Macwilliam, I. C. (1970). The structure, synthesis and functions of the yeast cell wall - a review. J. Inst. Brew. 76, 524-535.

Maldonado, G., Gorocica, P., Agundis, C., Perez, A., Molina, J., and Zenteno, E. (1998). Inhibition of phagocytic activity by the $N$-acetyl-Dgalactosamine-specific lectin from Amaranthus leucocarpus. Glycoconj. J. 15, 615-622.

Maldonado, G., Porras, F., Fernandez, L., Vazquez, L., and Zenteno, E. (1994). Effect of lectins on mouse peritoneal macrophage phagocytic activity. Immunol. Invest. 23, 429-436. 
Maresca, B., and Kobayashi, G. S. (1989). Dimorphism in Histoplasma capsulatum: a model for the study of cell differentiation in pathogenic fungi. Microbiol. Rev. 53, 186-209.

Marion, C. L., Rappleye, C. A., Engle, J. T., and Goldman, W. E. (2006). An alpha-(1,4)-amylase is essential for alpha-(1,3)-glucan production and virulence in Histoplasma capsulatum. Mol. Microbiol. 62, 970-983.

Matsuo, A. L., Tersariol, Ii, Kobata, S. I., Travassos, L. R., Carmona, A. K., and Puccia, R. (2006). Modulation of the exocellular serine-thiol proteinase activity of Paracoccidioides brasiliensis by neutral polysaccharides. Microbes Infect. 8, 84-91.

Mcmahon, J. P., Wheat, J., Sobel, M. E., Pasula, R., Downing, J. F., and Martin, W. J. II. (1995). Murine laminin binds to Histoplasma capsulatum. A possible mechanism of dissemination. J. Clin. Invest. 96, 1010-1017.

Mecheri, S., Dannecker, G., Dennig, D., Poncet, P., and Hoffmann, M. K. (1993). Anti-histone autoantibodies react specifically with the $\mathrm{B}$ cell surface. Mol. Immunol. 30, 549-557.

Medeiros, A. I., Malheiro, A., Jose, P. J., Conroy, D. M., Williams, T. J., and Faccioli, L. H. (2004). Differential release of MIP-1alpha and eotaxin during infection of mice by Histoplasma capsulatum or inoculation of beta-glucan. Inflamm. Res. 53, 351-354.

Medeiros, A. I., Silva, C. L., Malheiro, A., Maffei, C. M., and Faccioli, L. H. (1999). Leukotrienes are involved in leukocyte recruitment induced by live Histoplasma capsulatum or by the beta-glucan present in their cell wall. Br. J. Pharmacol. 128, 1529-1537.

Meloan, E. L. (1952). Histoplasmosis. Miss. Doct. 29, 256-257.

Mendes-Giannini, M. J., Taylor, M. L., Bouchara, J. B., Burger, E., Calich, V. L., Escalante, E. D., Hanna, S. A., Lenzi, H. L., Machado, M. P., Miyaji, M., Monteiro Da Silva, J. L., Mota, E. M., Restrepo, A., Restrepo, S., Tronchin, G., Vincenzi, L. R., Xidieh, C. F., and Zenteno, E. (2000). Pathogenesis II: fungal responses to host responses: interaction of host cells with fungi. Med. Mycol. 38(Suppl. 1), 113-123.

Minchiotti, G., Gargano, S., and Maresca, B. (1992). Molecular cloning and expression of hsp82 gene of the dimorphic pathogenic fungus Histoplasma capsulatum. Biochem. Biophys. Acta 1131, 103-107.

Mol, P. C., and Wessels, J. G. H. (1987). Linkages between glucosaminogly- can and glucan determine alkaliinsolubility of the glucan in walls of Saccharomyces cerevisiae. FEMS Microbiol. Lett. 41, 95-99.

Mora-Montes, H. M., Netea, M. G., Ferwerda, G., Lenardon, M. D., Brown, G. D., Mistry, A. R., Kullberg, B. J., O'callaghan, C. A., Sheth, C. C., Odds, F. C., Brown, A. J., Munro, C. A., Gow, N. A., and Deepe, G. S. Jr. (2011). Recognition and blocking of innate immunity cells by Candida albicans chitin. Infect. Immun. 79, 1961-1970.

Newman, S. L. (2005). Interaction of Histoplasma capsulatum with human macrophages, dendritic cells, and neutrophils. Methods Mol. Med. 118, 181-191.

Newman, S. L., Lemen, W., and Smulian, A. G. (2011). Dendritic cells restrict the transformation of Histoplasma capsulatum conidia into yeasts. Med. Mycol. 49, 356-364.

Nimrichter, L., Barreto-Bergter, E., Mendonca-Filho, R. R., Kneipp, L. F., Mazzi, M. T., Salve, P., Farias, S. E., Wait, R., Alviano, C. S., and Rodrigues, M. L. (2004). A monoclonal antibody to glucosylceramide inhibits the growth of Fonsecaea pedrosoi and enhances the antifungal action of mouse macrophages. Microbes Infect. 6, 657-665.

Nosanchuk, J. D. (2005). Protective antibodies and endemic dimorphic fungi. Curr. Mol. Med. 5, 435-442.

Nosanchuk, J. D., and Casadevall, A. (2006). Impact of melanin on microbial virulence and clinical resistance to antimicrobial compounds. Antimicrob. Agents Chemother. 50, 3519-3528.

Nosanchuk, J. D., Gomez, B. L., Youngchim, S., Diez, S., Aisen, P., Zancope-Oliveira, R. M., Restrepo, A., Casadevall, A., and Hamilton, A. J. (2002). Histoplasma capsulatum synthesizes melanin-like pigments in vitro and during mammalian infection. Infect. Immun. 70, 5124-5131.

Nosanchuk, J. D., Steenbergen, J. N., Shi, L., Deepe, G. S. Jr., and Casadevall, A. (2003). Antibodies to a cell surface histone-like protein protect against Histoplasma capsulatum. J. Clin. Invest. 112, 1164-1175.

Ojcius, D. M., Muller, S., HasselkusLight, C. S., Young, J. D., and Jiang, S. (1991). Plasma membraneassociated proteins with the ability to partially inhibit perforinmediated lysis. Immunol. Lett. 28, 101-108.

Oliveira, D. L., Freire-De-Lima, C. G., Nosanchuk, J. D., Casadevall, A., Rodrigues, M. L., and Nimrichter, L. (2010). Extracellular vesicles from Cryptococcus neoformans modulate macrophage functions. Infect. Immun. 78, 1601-1609.

Pessolani, M. C., Hunter, S. W., and Brennan, P. J. (1993). Relationship between host histones and armadillo-derived Mycobacterium leprae. Int. J. Lepr. Other Mycobact. Dis. 61, 381-388.

Pethe, K., Puech, V., Daffe, M., Josenhans, C., Drobecq, H., Locht, C., and Menozzi, F. D. (2001) Mycobacterium smegmatis lamininbinding glycoprotein shares epitopes with Mycobacterium tuberculosis heparin-binding haemagglutinin. Mol. Microbiol. 39, 89-99.

Pietrella, D., Bistoni, G., Corbucci, C., Perito, S., and Vecchiarelli, A. (2006). Candida albicans mannoprotein influences the biological function of dendritic cells. Cell. Microbiol. 8, 602-612.

Pietrella, D., Lupo, P., Rachini, A., Sandini, S., Ciervo, A., Perito, S., Bistoni, F., and Vecchiarelli, A. (2008). A Candida albicans mannoprotein deprived of its mannan moiety is efficiently taken up and processed by human dendritic cells and induces T-cell activation without stimulating proinflammatory cytokine production. Infect. Immun. 76, 4359-4367.

Pine, L. (1960). "Morphological and physiological characteristics of Histoplasma capsulatum," in Histoplasmosis (Springfield, IL: CC Thomas), 40-75.

Pinto, M. R., Rodrigues, M. L., Travassos, L. R., Haido, R. M., Wait, R., and Barreto-Bergter, E. (2002). Characterization of glucosylceramides in Pseudallescheria boydii and their involvement in fungal differentiation. Glycobiology 12, 251-260.

Rappleye, C. A., Eissenberg, L. G., and Goldman, W. E. (2007). Histoplasma capsulatum alpha-(1,3)-glucan blocks innate immune recognition by the beta-glucan receptor. Proc. Natl. Acad. Sci. U.S.A. 104, 1366-1370.

Rappleye, C. A., Engle, J. T., and Goldman, W. E. (2004). RNA interference in Histoplasma capsulatum demonstrates a role for alpha-(1,3)-glucan in virulence. Mol. Microbiol. 53, 153-165.

Reiss, E. (1977). Serial enzymatic hydrolysis of cell walls of two serotypes of yeast-form Histoplasma capsulatum with alpha(1 leads to 3)-glucanase, beta(1 leads to 3)glucanase, pronase, and chitinase. Infect. Immun. 16, 181-188.

Reiss, E., Miller, S. E., Kaplan, W. and Kaufman, L. (1977). Antigenic, chemical, and structural properties of cell walls of Histoplasma capsulatum yeast-form chemotypes 1 and 2 after serial enzymatic hydrolysis. Infect. Immun. 16, 690-700.

Reiss, E., Mitchell, W. O., Stone, S. H., and Hasenclever, H. F. (1974). Cellular immune activity of a galactomannan-protein complex from mycelia of Histoplasma capsulatum. Infect. Immun. 10 , 802-809.

Rekvig, O. P., Muller, S., Briand, J. P., Skogen, B., and Van Regenmortel, M. H. (1987). Human antinuclear autoantibodies crossreacting with the plasma membrane and the N-terminal region of histone H2B. Immunol. Invest. 16, 535-547.

Rementeria, A., Abaitua, F., GarciaTobalina, R., Hernando, F., Ponton, J., and Sevilla, M. J. (1997). Resistance to candidiasis and macrophage activity in chitin-treated mice. FEMS Immunol. Med. Microbiol. 19, 223-230.

Rodrigues, M. L., Nakayasu, E. S., Oliveira, D. L., Nimrichter, L., Nosanchuk, J. D., Almeida, I. C., and Casadevall, A. (2008a). Extracellular vesicles produced by Cryptococcus neoformans contain protein components associated with virulence. Eukaryot. Cell 7, 58-67.

Rodrigues, M. L., Nimrichter, L., Oliveira, D. L., Nosanchuk, J. D., and Casadevall, A. (2008b). Vesicular trans-cell wall transport in fungi: a mechanism for the delivery of virulence-associated macromolecules? Lipid Insights 2, 27-40.

Rodrigues, M. L., Nimrichter, L. Oliveira, D. L., Frases, S., Miranda, K., Zaragoza, O., Alvarez, M., Nakouzi, A., Feldmesser, M., and Casadevall, A. (2007). Vesicular polysaccharide export in Cryptococcus neoformans is a eukaryotic solution to the problem of fungal transcell wall transport. Eukaryot. Cell 6, 48-59.

Rodrigues, M. L., Travassos, L. R., Miranda, K. R., Franzen, A. J., Rozental, S., De Souza, W., Alviano, C. S., and Barreto-Bergter, E. (2000). Human antibodies against a purified glucosylceramide from Cryptococcus neoformans inhibit cell budding and fungal growth. Infect. Immun. 68 , 7049-7060.

Ross, G. D. (2002). Role of the lectin domain of Mac-1/CR3 (CD11b/CD18) in regulating intercellular adhesion. Immunol. Res. 25, 219-227.

Ruiz-Herrera, J., and Osorio, E. (1974). Isolation and chemical analysis of the cell wall of Morchella sp. Antonie Van Leeuwenhoek 40, 57-64. 
Saibil, H. R. (2008). Chaperone machines in action. Curr. Opin. Struct. Biol. 18, 35-42.

Saliba, A., and Beatty, O. A. (1960). Pulmonary histoplasmosis, importance of diagnostic methods, with report of an early case. JAMA 173, 902-904.

Santoro, M. G. (2000). Heat shock factors and the control of the stress response. Biochem. Pharmacol. 59, 55-63.

Scheckelhoff, M., and Deepe, G. S. Jr. (2005). A deficiency in gamma interferon or interleukin-10 modulates T-Cell-dependent responses to heat shock protein 60 from Histoplasma capsulatum. Infect. Immun. 73, 2129-2134.

Schlosser, A., Thomsen, T., Moeller, J. B., Nielsen, O., Tornoe, I., Mollenhauer, J., Moestrup, S. K., and Holmskov, U. (2009). Characterization of FIBCD1 as an acetyl group-binding receptor that binds chitin. J. Immunol. 183, 3800-3809.

Serrano-Gomez, D., Leal, J. A., and Corbi, A. L. (2005). DC-SIGN mediates the binding of Aspergillus fumigatus and keratinophylic fungi by human dendritic cells. Immunobiology 210, 175-183.

Shaner, L., Gibney, P. A., and Morano, K. A. (2008). The Hsp110 protein chaperone Sse1 is required for yeast cell wall integrity and morphogenesis. Curr. Genet. 54, 1-11.

Sharon, N. (1984). Carbohydrates as recognition determinants in phagocytosis and in lectin-mediated killing of target cells. Biol. Cell 51, 239-245.

Shearer, G. Jr., Birge, C. H., Yuckenberg, P. D., Kobayashi, G. S., and Medoff, G. (1987). Heat-shock proteins induced during the mycelial-toyeast transitions of strains of Histoplasma capsulatum. J. Gen. Microbiol. 133, 3375-3382.

Shi, L., Albuquerque, P. C., LazarMolnar, E., Wang, X., Santambrogio, L., Gacser, A., and Nosanchuk, J. D. (2008). A monoclonal antibody to Histoplasma capsulatum alters the intracellular fate of the fungus in murine macrophages. Eukaryot. Cell 7, 1109-1117.

Shimoji, Y., Ng, V., Matsumura, K., Fischetti, V. A., and Rambukkana, A. (1999). A 21-kDa surface protein of Mycobacterium leprae binds peripheral nerve laminin-2 and mediates Schwann cell invasion. Proc. Natl. Acad. Sci. U.S.A. 96, 9857-9862.
Singh, R. S., Bhari, R., Rana, V., and Tiwary, A. K. (2011). Immunomodulatory and therapeutic potential of a mycelial lectin from Aspergillus nidulans. Appl. Biochem. Biotechnol. 165, 624-638.

Smith, C. D. (1971a). "Nutritional factors that are required for the growth and sporulation of Histoplasma capsulatum," in Histoplasmosis. Proceedings of the Second National Conference, eds L. Ajello, E. W. Chick, and M. L. Furcolow (Springfield, IL: C Thomas), 64-70.

Smith, C. D. (1971b). "The role of birds in the ecology of Histoplasma capsulatum," in Histoplasmosis. Proceedings of the Second National Conference, eds L. Ajello, E. W. Chick, and M. L. Furcolow (Springfield, IL: C Thomas), 140-148.

Steele, C., Rapaka, R. R., Metz, A., Pop, S. M., Williams, D. L., Gordon, S., Kolls, J. K., and Brown, G. D. (2005). The beta-glucan receptor dectin1 recognizes specific morphologies of Aspergillus fumigatus. PLoS Pathog. 1, e42. doi:10.1371/journal.ppat.0010042

Strasser, J. E., Newman, S. L., Ciraolo, G. M., Morris, R. E., Howell, M. L., and Dean, G. E. (1999). Regulation of the macrophage vacuolar ATPase and phagosome-lysosome fusion by Histoplasma capsulatum. J. Immunol. 162, 6148-6154.

Taborda, C. P., Da Silva, M. B., Nosanchuk, J. D., and Travassos, L. R. (2008). Melanin as a virulence factor of Paracoccidioides brasiliensis and other dimorphic pathogenic fungi: a minireview. Mycopathologia 165, 331-339.

Taylor, M. L., Duarte-Escalante, E., Perez, A., Zenteno, E., and Toriello, C. (2004). Histoplasma capsulatum yeast cells attach and agglutinate human erythrocytes. Med. Mycol.42, 287-292.

Taylor, M. L., Duarte-Escalante, E., Reyes-Montes, M. R., Elizondo, N., Maldonado, G., and Zenteno, E. (1998). Interaction of murine macrophage-membrane proteins with components of the pathogenic fungus Histoplasma capsulatum. Clin. Exp. Immunol. 113, 423-428.

Toledo, M. S., Levery, S. B., Suzuki, E., Straus, A. H., and Takahashi, H. K. (2001a). Characterization of cerebrosides from the thermally dimorphic mycopathogen Histoplasma capsulatum: expression of 2hydroxy fatty $N$-acyl (E)-Delta(3)unsaturation correlates with the yeast-mycelium phase transition. Glycobiology 11, 113-124.

Toledo, M. S., Suzuki, E., Levery, S. B. Straus, A. H., and Takahashi, H. K. (2001b). Characterization of monoclonal antibody MEST-2 specific to glucosylceramide of fungi and plants. Glycobiology 11, 105-112.

Torosantucci, A., Bromuro, C., Chiani, P., De Bernardis, F., Berti, F., Galli, C., Norelli, F., Bellucci, C., Polonelli, L., Costantino, P., Rappuoli, R., and Cassone, A. (2005). A novel glyco-conjugate vaccine against fungal pathogens. J. Exp. Med. 202, 597-606.

Vallejo, M. C., Matsuo, A. L., Ganiko, L., Medeiros, L. C., Miranda, K., Silva, L. S., Freymuller-Haapalainen, E., Sinigaglia-Coimbra, R., Almeida, I. C., and Puccia, R. (2011). The pathogenic fungus Paracoccidioides brasiliensis exports extracellular vesicles containing highly immunogenic alpha-Galactosyl epitopes. Eukaryot. Cell 10, 343-351.

Van Duin, D., Casadevall, A., and Nosanchuk, J. D. (2002). Melanization of Cryptococcus neoformans and Histoplasma capsulatum reduces their susceptibilities to amphotericin $\mathrm{B}$ and caspofungin. Antimicrob. Agents Chemother. 46, 3394-3400.

Wheat, J. (1994). Histoplasmosis: recognition and treatment. Clin. Infect. Dis. 19(Suppl. 1), S19-S27.

Wheat, J. (1996). Histoplasmosis in the acquired immunodeficiency syndrome. Curr. Top. Med. Mycol. 7, 7-18.

Wheat, J. (1997). Histoplasmosis. Experience during outbreaks in Indianapolis and review of the literature. Medicine (Baltimore) 76, 339-354.

Wheat, L. J. (2001). Laboratory diagnosis of histoplasmosis: update 2000 Semin. Respir. Infect. 16, 131-140.

Wheat, L. J., Connolly-Stringfield, P. A. and Baker, R. L. (1990). Disseminated histoplasmosis in the acquired immune deficiency syndrome: clinical findings, diagnosis and treatment, and review of the literature. Medicine (Baltimore) 69, 361-374

Wheat, L. J., Freifeld, A. G., Kleiman, M. B., Baddley, J. W., Mckinsey, D. S., Loyd, J. E., and Kauffman, C. A. (2007). Clinical practice guidelines for the management of patients with histoplasmosis: 2007 update by the Infectious Diseases Society of America. Clin. Infect. Dis. 45, 807-825.

Wheat, L. J., and Kauffman, C. A (2003). Histoplasmosis. Infect. Dis. Clin. North Am. 17, 1-19, vii.
Woodward, J., and Wiseman, A. (1982). Fungal and other beta-glucosidases - their properties and applications. Enzyme Microb. Technol. 4, 73-79.

Wu, C. (1995). Heat shock transcription factors: structure and regulation. Annu. Rev. Cell Dev. Biol. 11, 441-469.

Yoneda, A., and Doering, T. L. (2006) A eukaryotic capsular polysaccharide is synthesized intracellularly and secreted via exocytosis. Mol. Biol. Cell 17, 5131-5140.

Zancope-Oliveira, R. M., Bragg, S. L., Reiss, E., and Peralta, J. M. (1994). Immunochemical analysis of the $\mathrm{H}$ and $\mathrm{M}$ glycoproteins from Histoplasma capsulatum. Clin. Diagn. Lab. Immunol. 1, 563-568.

Zancopé-Oliveira, R. M., Reiss, E., Lott, T. J., Mayer, L. W., and Deepe, G. S. Jr. (1999). Molecular cloning, characterization, and expression of the $\mathrm{M}$ antigen of Histoplasma capsulatum. Infect. Immun. 67, 1947-1953.

Zancope-Oliveira, R. M., Silva Tavares, P. M. E., and De Medeiros Muniz, M (2005). Genetic diversity of Histoplasma capsulatum strains in Brazil. FEMS Immunol. Med. Microbiol. 45, 443-449.

Zeidberg, L. D., Ajello, L., Dillon, A. and Runyon, L. C. (1952). Isolation of Histoplasma capsulatum from soil. Am. J. Public Health 42, 930-935.

Conflict of Interest Statement: The authors declare that the research was conducted in the absence of any commercial or financial relationships that could be construed as a potential conflict of interest.

Received: 30 August 2011; paper pending published: 16 September 2011; accepted: 25 October 2011; published online: 18 November 2011.

Citation: Guimarães AJ, de Cerqueira MD and Nosanchuk JD (2011) Surface architecture of Histoplasma capsulatum. Front. Microbio. 2:225. doi: 10.3389/fmicb.2011.00225

This article was submitted to Frontiers in Fungi and Their Interactions, a specialty of Frontiers in Microbiology.

Copyright (C) 2011 Guimarães, de Cerqueira and Nosanchuk. This is an open-access article subject to a nonexclusive license between the authors and Frontiers Media SA, which permits use, distribution and reproduction in other forums, provided the original authors and source are credited and other Frontiers conditions are complied with. 